1979

\title{
Archaeological Testing at Fort McIntosh, Laredo Junior College Campus, Laredo, Texas
}

Daniel E. Fox

Follow this and additional works at: https://scholarworks.sfasu.edu/ita

Part of the American Material Culture Commons, Archaeological Anthropology Commons, Environmental Studies Commons, Other American Studies Commons, Other Arts and Humanities Commons, Other History of Art, Architecture, and Archaeology Commons, and the United States History Commons

Tell us how this article helped you.

This Article is brought to you for free and open access by the Center for Regional Heritage Research at SFA ScholarWorks. It has been accepted for inclusion in Index of Texas Archaeology: Open Access Gray Literature from the Lone Star State by an authorized editor of SFA ScholarWorks. For more information, please contact cdsscholarworks@sfasu.edu. 


\section{Archaeological Testing at Fort McIntosh, Laredo Junior College Campus, Laredo,}

Texas

\section{Creative Commons License}

\section{(c) (1) (8)}

This work is licensed under a Creative Commons Attribution-NonCommercial 4.0 International License 


\section{Archaeological Tesfing af Porr Melntosh, Laredo Junior College Campus, Laredo, Texas}

Daniel P.Pox

Center for Archaedogical Fesearch

The University of Toxas at Ban Antonio

San Antonin, Texas 79205

Center for Archaeological Research

The University of Texas at San Antonio Archaeologica! Survey-Report, No.68

1979 
The following information is provided in accordance with General Rule of Practice and Procedure, 355.01.017C, Texas Antiquities Committee:

1. Archaeological test excavations of portions of the Laredo Junior College campus;

2. Fort McIntosh, Laredo Junior College carnpus;

3. Webb County, Texas;

4. Thomas R. Hester, Principal Investigator; Daniel E. Fox, Author;

5. Laredo Junior College;

6. Texas Historical Commission Antiquities Permit No. 150;

7. Published by the Center for Archaeological Research, The University of Texas at San Antonio, San Antonio, Texas 78285; June 1979. 


\title{
ARCHAEOLOGICAL TESTING AT FORT MCINTOSH, LAREDO JUNIOR COLLEGE CAMPUS, LAREDO, TEXAS
}

Center for Archasological Research

The University of Texas at San Antonio San Antunio, Tevas 78285

\author{
Daniel E. Fox
}

Center for Archaeological Research The University of Texas at San Antonio Archaeological Survey Report, No. 68 
TABLE OF CONTENTS

Page

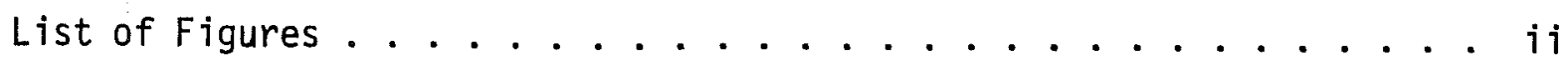

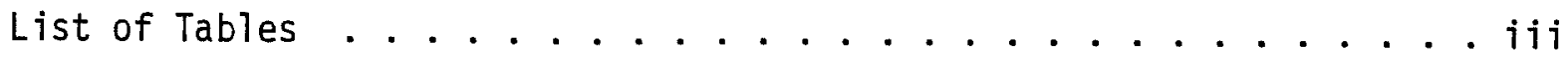
Acknowledgments ...................... iv Introduction ......................... . . 1 Related Archaeological Investigations . . . . . . . . . . . . 1 Historical Background...................... 3 Methodology ........................ 5 Features ........................ 10 Material Culture ...................... 17 Summary and Conclusions .................... 26 References cited ....................... 31

i 


\section{LIST OF FIGURES}

Figure

Page

1. Plan of Fort McIntosh Showing Archaeological Project

Areas .......................... 2

2. Views of Standing Fort Structures . . . . . . . . . . . 4

3. Plan of Southern ("Stables") Part of Tennis Courts Area . . . . . 6

4. Plan of Tennis Courts Area Showing Locations of Backhoe

Trenches and T-6..................... . 7

5. Plan of Northern ("Post Garden") Part of Tennis Courts Area . . . 8

6. Views of Tennis Courts Area . . . . . . . . . . . . . 11

7. Plan of Trench 1 (T-1) Showing Archaeological Features . . . . 12

8. Cross Sections Through Trench T $(T-1)$. . . . . . . . . . . 14

9. West (Northwest) Profile of Backhoe Trench 1 (BH-1) . . . . . . 15

10. West (Northwest) Profile of Trench 6 (T-6) . . . . . . . . 16

11. Glass Artifacts .................... . . 18

12. Glass Artifacts ..................... . . 19

13. Ceramic Sherds and Pipe Fragments . . . . . . . . . . . . . 24

14. Personal Items . . . . . . . . . . . . . . . . . 27 


\section{LIST OF TABLES}

Table

Page

1. Fort McIntosh (41 WB 11) Athletic Area Construction

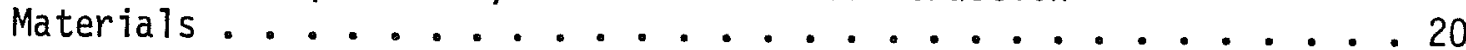

2. Fort McIntosh (41 WB 11) Athletic Area Food-, Medicineand Beverage-Related Materials, and Household Garbage . . . . . 21

3. Fort McIntosh (41 WB 11) Athletic Area Personal Items, Harness Trappings, Firearms and Miscellaneous Items . . . . . . 22

4. Ceramic Dates and Origins . . . . . . . . . . . . . 25

5. Distribution of Chronological Diagnostics in Tennis Court Area ....................... . 29

6. Distribution of Kinds and Amounts of Historic Cultural Material in Tennis Court Area . . . . . . . . . . . 30 
Several people contributed to the field investigation of Fort McIntosh and to the production of this report on the archaeology of proposed tennis courts and parking facilities areas. Archaeologists Thomas Medlin and Jon McClenny, with James Ivey as consultant, were responsible for the field work and offered valuable assistance to the author during the write-up of the project. The interest and cooperation of officials of Laredo Junior College are greatly appreciated.

Volunteers from the Webb County Archaeological Society and from Laredo Junior College and Laredo State University donated their time to help with the field work. The Laredo Road Department loaned a maintainer for use in the project.

Jerry Thompson aided greatly with historical research. Sam Nesmith of the Institute of Texan Cultures helped identify some of the military-related artifacts. Becky Halpern of the Center for Archaeological Research, The University of Texas at San Antonio, made a cursory inspection of the faunal remains and food bone samples. Thomas R. Hester, Ph.D., Director of the Center for Archaeological Research, served as Principal Investigator; Jack D. Eaton, Assistant Director, provided supervision for the project. 
From July 6 to 31, 1977, archaeologists from the Center for Archaeological Research, The University of Texas at San Antonio (UTSA), conducted archaeological investigations at Fort McIntosh (41 WB 11), Laredo, Texas. The purpose of this investigation was to make an assessment of areas to be affected by planned tennis courts and parking facilities on the Laredo Junior College campus.

The archaeological investigation was done under contract between Laredo Junior College (Dr. Domingo Arechiga, President) and the Center for Archaeological Research, UTSA. The field work was accompl ished by Thomas Medlin, crew chief, and Jon McClenny, assistant, with the help of interested college students and amateur archaeologists, under the general supervision of $\mathrm{Dr}$. Thomas R. Hester, Director of the Center, and Mr. Jack D. Eaton, Assistant Director.

The following report was prepared from field records, maps and artifacts stored at the Center for Archaeological Research, from information gathered through extended conversations with Medl in and McClenny and from Medl in's (1977b) preliminary report on the investigation.

\section{RELATED ARCHAEOLOGICAL INVESTIGATIONS}

During Spring 1977, an initial archaeological assessment of areas proposed for modification at Fort McIntosh was made by the Center for Archaeological Research (Ivey, Medlin and Eaton 1977). At that time, the development of athletic and parking facilities was planned for an unused open area of the Laredo Junior College campus lying between the college buildings and the Rio Grande (Fig. 1). A surface survey of this area noted concentrations of artifacts relating to early (pre-Civil War) and later (post-1860) periods during which the Fort was occupied. Limited subsurface testing recovered post-1860 artifacts. Structural and artifactual evidence of the early Fort was not recognized. However, the investigators suggested that earlier evidence might be buried beneath layers of flood-deposited silts, and that archaeological traces, if and when they were found, would occur in the form of artifact concentrations, post holes, and possibly stone foundation remains (Ivey, Medlin and Eaton 1977:15-19).

Subsequent to this initial assessment, short-term archaeological survey and testing investigations were made of the parade ground and officers' quarters areas of the later Fort, where construction activities were planned by Laredo Junior College and Laredo State University (Fox 1978a, 1978b; Medl in 1977a). The only archaeological evidence encountered in these project areas was the remains of a wire-wound wooden water pipeline which ran north-south across the parade ground of the later Fort.

As a second phase, following the initial archaeological assessment of Fort McIntosh (Ivey, Med7 in and Eaton 1977), subsurface testing was carried out (Medl in 1977b) in areas scheduled for the development of tennis courts and parking facilities in the southwestern part of the campus in the area where both early and later forts were located. The following is a report of that investigation. 


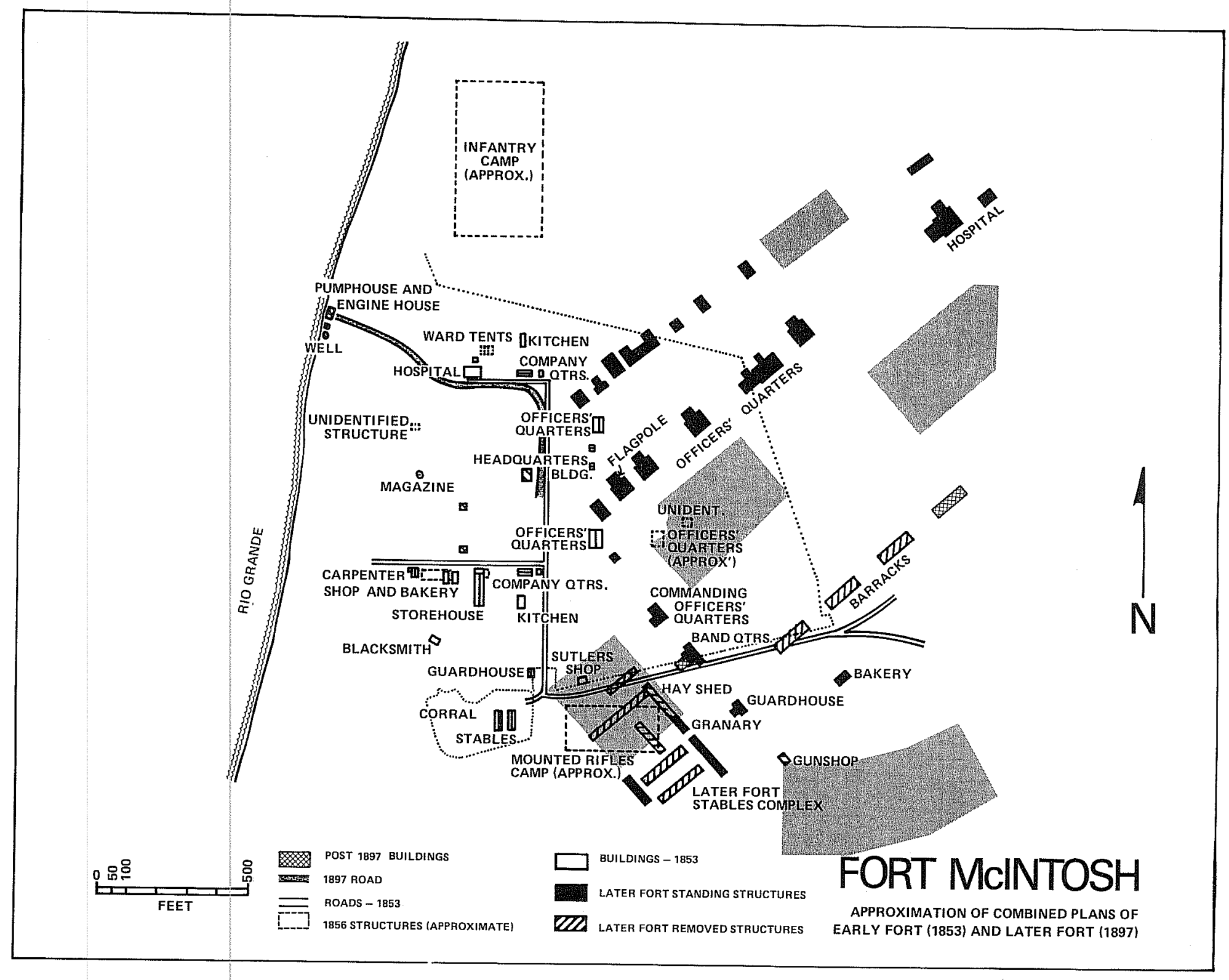

Figure 1. Plan of Fort McIntosh Showing Archaeological Project Areas. Shading indicates the locations of past and current archaeological investigations. 
The history of Fort McIntosh has been detailed el sewhere (cf. Thompson 1973, 1974 and Wilkinson 1975). Ivey, Medlin and Eaton (1977:1-3) present a summary of this history as it pertains to archaeological problems. For the purposes of this report, chronology of the occupation of Fort McIntosh and the historic background of the two specific project areas is appropriate.

\section{Pre-Civil War and Post-Civil War Fort McIntosh}

Officially established as Camp Crawford on March 3, 1849 and renamed on January 7, 1850 (Thompson 1974:165,166), Fort McIntosh consisted mainly of tents during the first few years. By July 1853, six wooden-frame and two stone structures had been built (Crimmins 1950:204). Fourteen frame structures had been added by November (National Archives 1953). By 1856, the star fort was complete and Fort McIntosh was occupied by four companies of infantry, two companies of mounted rifles and one company of artillery (Crimmins 1939:228239).

The Fort and cantonment were abandoned in March 1859, and 30 buildings were put up for sale at public auction. In February 1860, during the period of raiding by Juan Cortina, Fort McIntosh was reoccupied and operated until March 12, 1861 (Thompson 1974:187-192). Apparent7y, there was no construction at the Fort during the Civil War (Ivey, Medlin and Eaton 1977:2).

On October 23, 1865, Fort McIntosh was reoccupied (Thompson 1974:216). Tents were used as housing while a new post was constructed. By late 1872, several stone, adobe and frame structures had been built (Conway 1963:571). By 1875, other frame and adobe structures had been added (U.S. Army 1876:202-203). The use of yellow Laredo brick construction apparently began around 1880 (Ivey, Medlin and Eaton 1977:3), and in 1897, Fort McIntosh consisted of at least 40 buildings (National Archives 1897).

During the two world wars of the 20th century, there were build-ups of the post and subsequent dismantling of war-period structures. Fort McIntosh was closed officially as an Army post in 1946. Views of some of the presently standing Fort McIntosh buildings are shown in Fig. 2.

Ivey, Medlin and Eaton (1977:3) surmised that much of the early Fort was disturbed or obliterated by the construction of the later Fort and by 20 th century land modifications, although they suggested that it is likely that structural remains stil? survive.

Tennis Courts and Parking Facilities Areas

Ivey, Medl in and Eaton (1977:Fig. 2) have calculated that a sutler's store for the early Fort was located in the northern part of the tennis courts area and an early mounted rifles camp was in the vicinity of the southern part. From about the 1880s until World War II, the northern part was used as a post garden and the southern part was used for a horse stable (Fig. 1). 


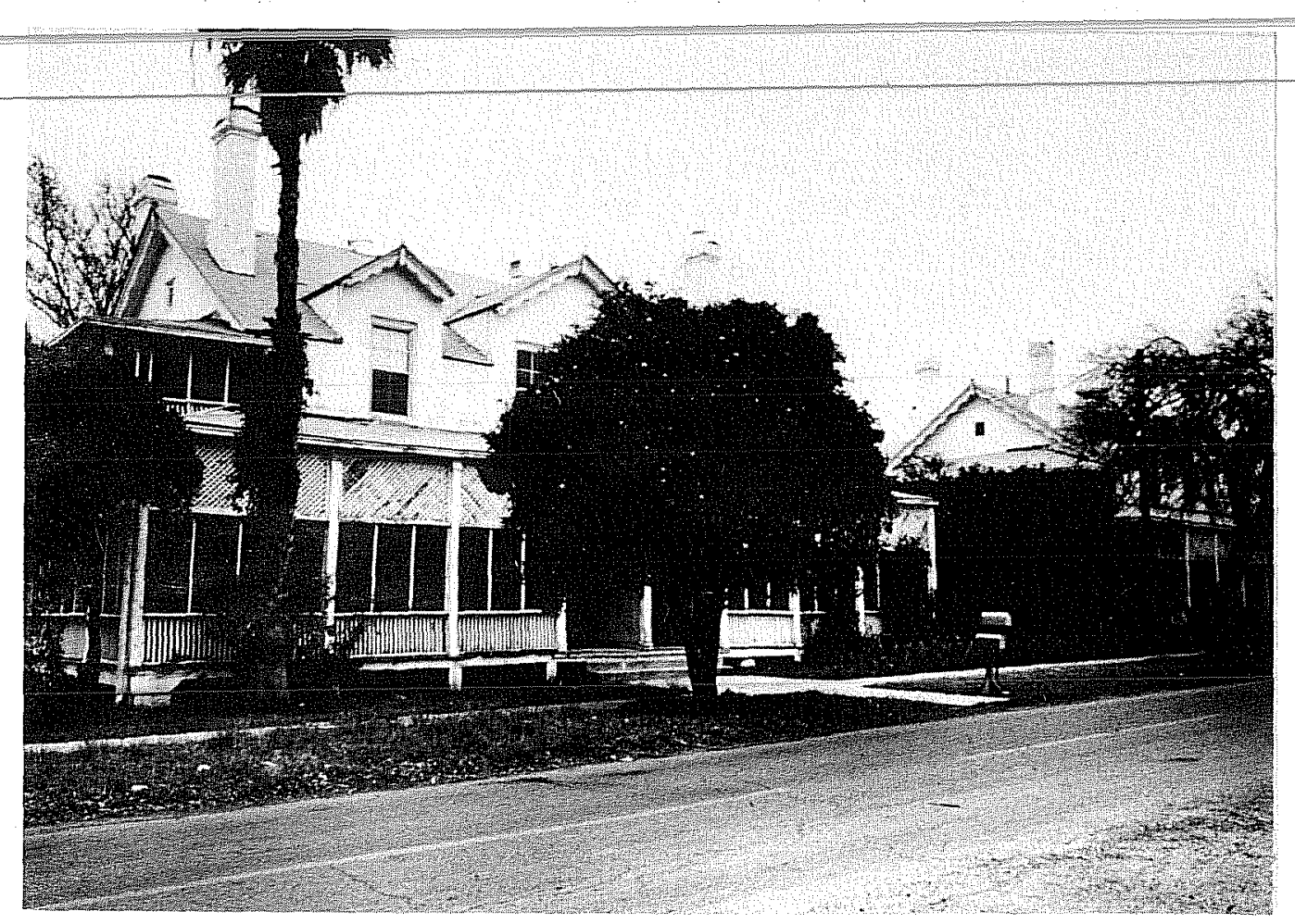

a

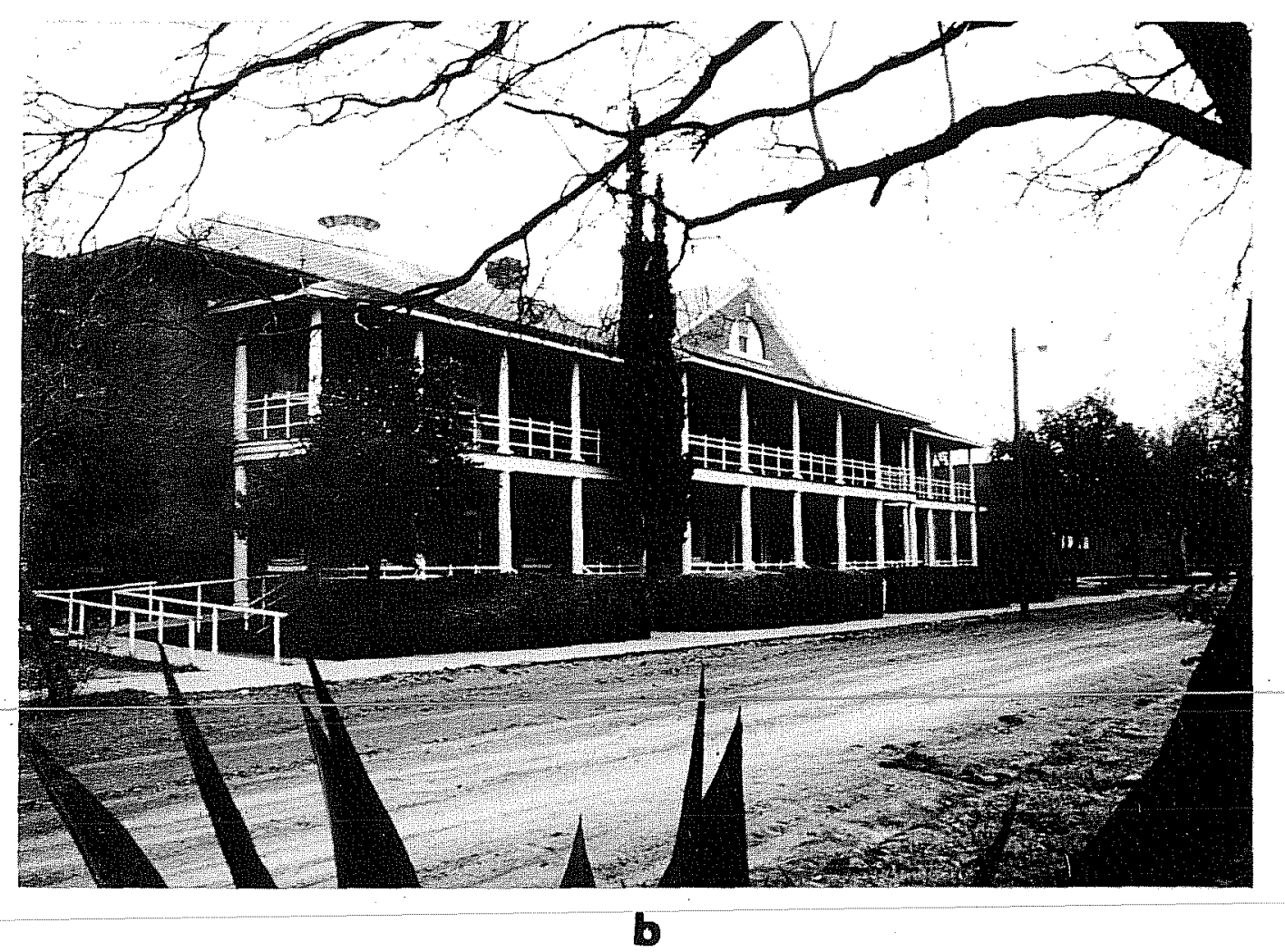

Figure 2. Views of Standing Fort Structures. a, officer's quarters on north side of old parade ground, now a private residence; b, enlisted men's barracks on south side of old parade ground, now the administrative offices of Laredo Junior College. 
Today, in the southern part of the tennis courts area, three buildings remain of eight shown on the 1897 map of the Fort (National Archives 1897; Ivey, Med1 in and Eaton 1977:Fig. 2; Med1 in 1977b:Figs. 2,3). The northern half is an open field.

There is no documentary evidence to indicate that the parking facility area (Fig. 1) was the site of any building construction during early or later Fort occupations.

\section{METHODOLOGY}

The archaeological testing of proposed tennis courts and parking facilities areas was oriented toward determining the nature and condition of subsurface evidence of early and late Fort McIntosh. During the initial survey (Ivey, Medlin and Eaton 1977), it was determined that there were some buried remains (wooden posts and a gravel pavement) of the later Fort stable. It was recommended that this southern ("Granary and Hayshed") part of the tennis courts area should be investigated more thoroughly. In addition, the northern ("Post Garden") part was tested for buried evidence of the early Fort. Subsurface testing of the proposed parking facilities area was also undertaken to verify suspicions that no archaeological evidence of Fort McIntosh would be affected in that project area.

\section{Tennis Courts Area}

The tennis courts were proposed to be located just west of Ainsworth Road in an open field northwest of the present Audio-Visual Center (Figs. 3,4). This building (P-19), once labeled the "Granary and Hayshed" (National Archives 1897), originally extended to the north. Four hand-dug test trenches $(T-1, T-2, T-4$ and $T-5)$ and a test pit (TP-1) were placed in the area of this northern extension of Building P-19 (Fig. 3) in the vicinity of earlier, more limited subsurface testing (Ivey, Medlin and Eaton 1977:Fig. 2). Another handdug test trench $(T-3)$ was placed in the open area west of Building $P-19$, and another ( $T-6)$ was placed north of Benavides Road (Fig. 4) in the northern ("Post Garden") part of the tennis courts area.

In addition, nine backhoe trenches and four maintainer cuts were excavated (Figs. 4,5). Five backhoe trenches were placed in a line running north from Building P-19, paralleling Ainsworth Road and crossing Benavides Road. The maintainer cuts and two backhoe trenches were placed in the vicinity of Test Trench $6(T-6)$, north of Benavides Road. The two remaining backhoe trenches were placed north of Buildings P-43, 44 and 45 and south of Benavides Road.

\section{Test Pit $1(T P-1)$}

This hand-dug test pit, measuring 39 inches square, was placed in the central part of the area where the north ("Hayshed") extension of Building P-19 once stood (Fig. 3). TP-1 was excavated to a depth of three feet below the ground surface to determine the soil stratigraphy for the southern ("Stables") part 


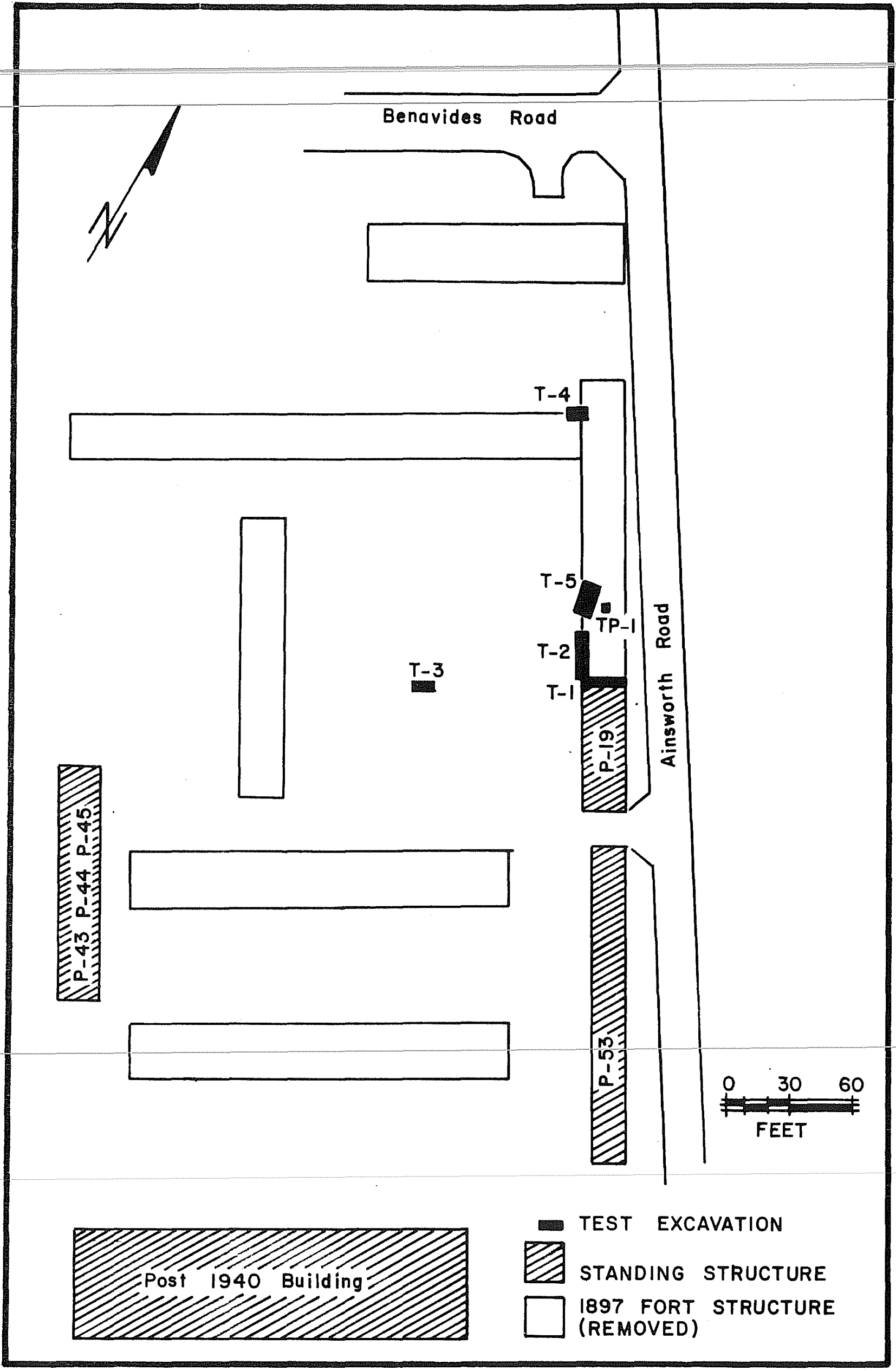

Figure 3. Plan of Southern ("Stables") Part of Tennis Courts Area. 


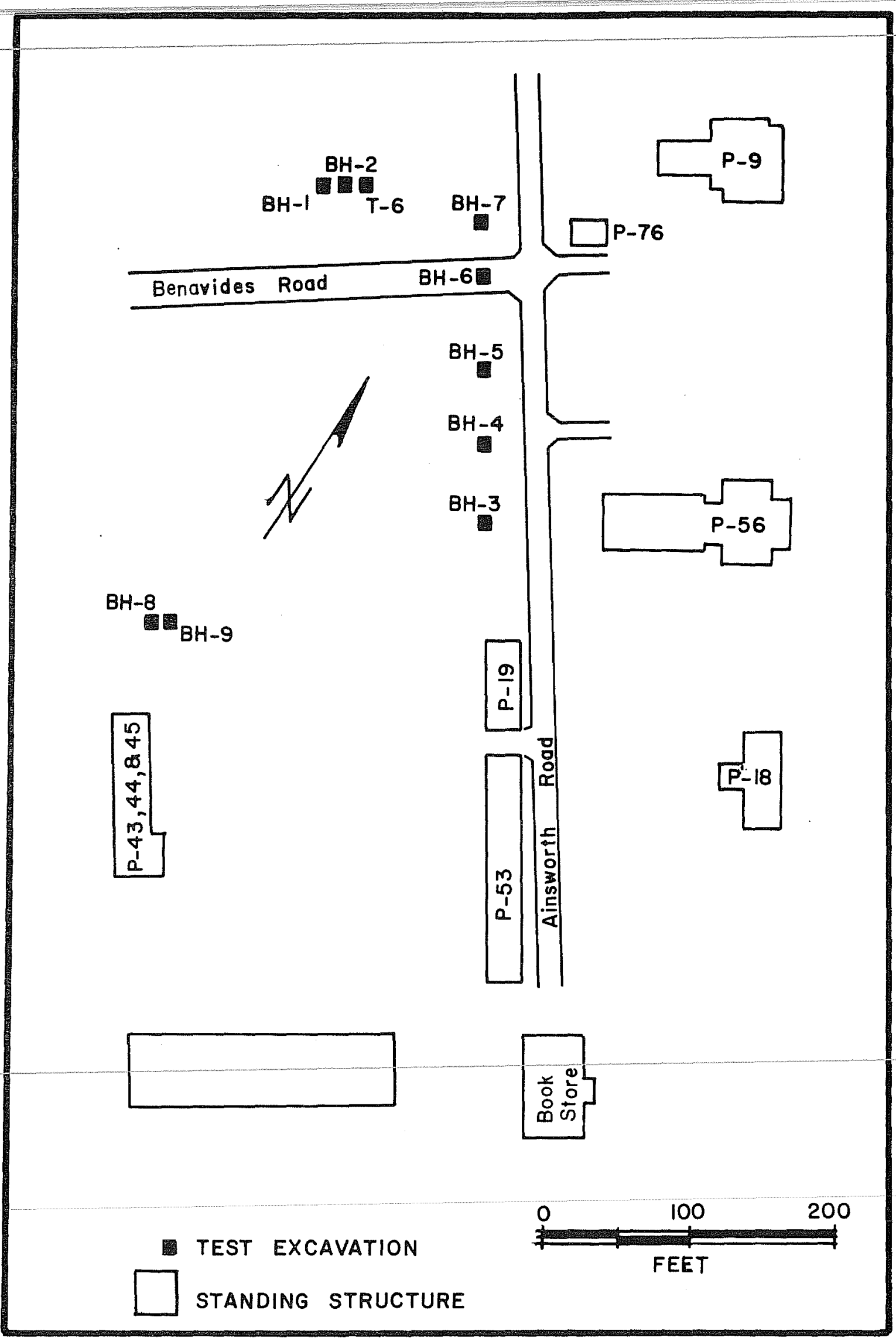

Figure 4. Plan of Tennis Courts Area Showing Locations of Backhoe Trenches and $T-6$. 


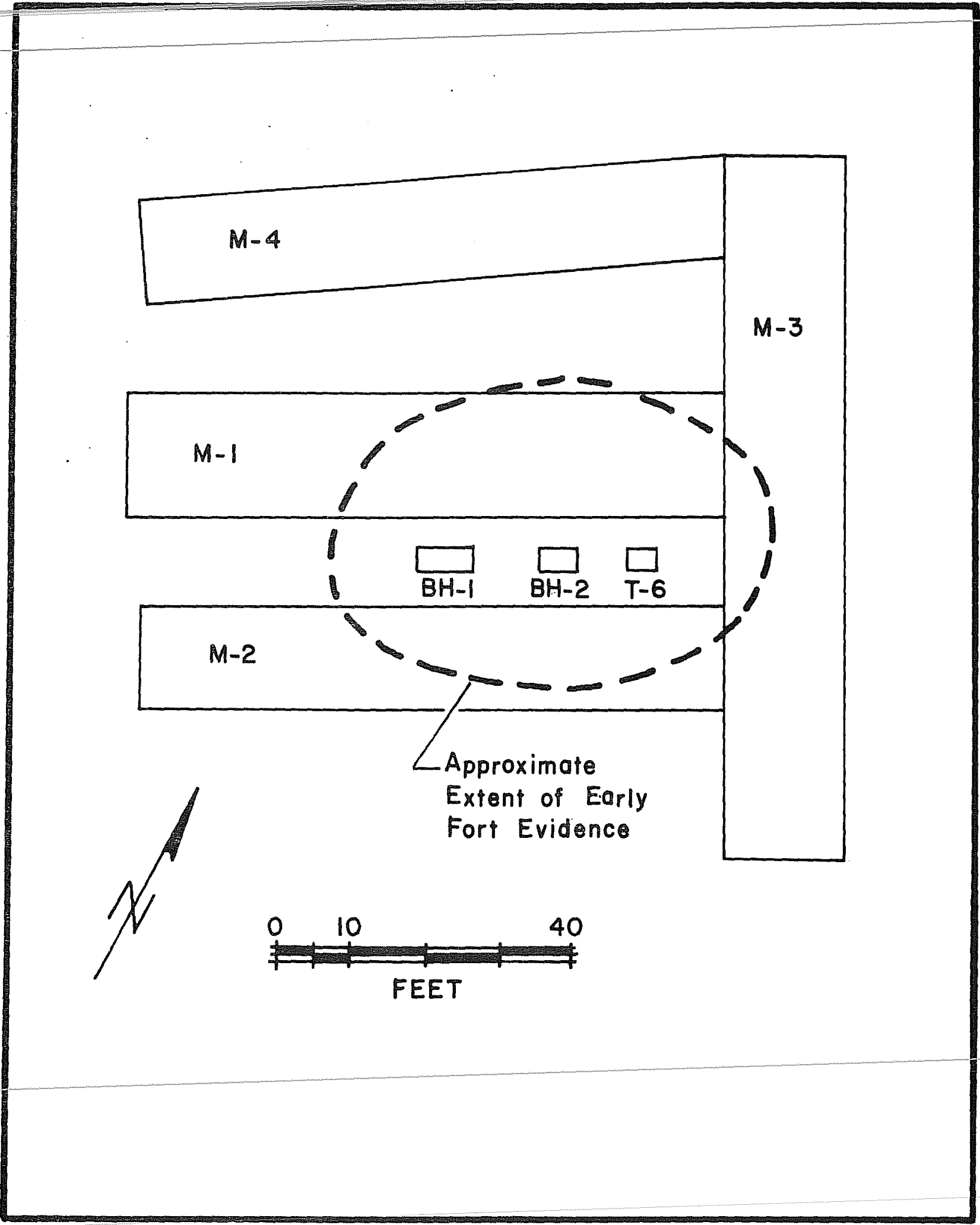

Figure 5. Plan of Northern ("Post Garden") Part of Tennis Courts Area. Shown here are locations of maintainer cuts, backhoe trenches and test pit. 
of the tenmis courts area. As noted in other excavations, the soil is flood deposited tan-gray sandy silt. In TP-1, intermittent hard-packed soil layers were observed which appear to be a series of old ground surfaces, each packed and baked hard during past exposures. In other parts of the later Fort stables area, soils apparently have been disturbed by mechanical clearing activities.

\section{Test Trenches}

Trench 1 (T-1), $22 \mathrm{ft} 8$ in long and $2 \mathrm{ft}$ wide, was dug along the north wall of Building $\mathrm{P}-19$ to a depth of approximately $1 \mathrm{ft} 8$ in below the ground surface (Fig. 3). Two posts, a post mold, a footing trench, a stone wall footing and a large amount of construction debris were encountered in $\mathrm{T}-1$.

Trench $2(T-2), 16 \mathrm{ft}$ long, $4 \mathrm{ft}$ wide and $1 \mathrm{ft} 7 \mathrm{in}$ deep, extended north from the west end of T-1 (Fig. 3) for a distance of $18 \mathrm{ft}$ from the north end wall of Building P-19 and was oriented parallel with the west face of that building. T-2 traversed a shallow subsurface layer of packed gravel.

Trench $3(\mathrm{~T}-3), 10 \mathrm{ft}$ long, $2 \mathrm{ft}$ wide and $1 \mathrm{ft}$ deep, was located $75 \mathrm{ft}$ west of Building $\mathrm{P}-19$ and in 1 ine with the north wall of that building (Fig. 3 ). The soil stratigraphy was notably confused in this area, apparently due to recent bulldozing. No structural evidence was found in T-3.

Trench $4(T-4), 10 \mathrm{ft}$ long and $4 \mathrm{ft}$ wide, was located $130 \mathrm{ft}$ north of Building P-19 and in line with the west wall of that building (Fig. 3). This is the approximate position of an intersection of the northern end of the west wall of Building P-19 ("Granary and Hayshed") and the northwest corner of another structure as shown on the 1897 map of the Fort. This linear structure was oriented perpendicular to Building P-19. T-4 was excavated to a depth of $2 \mathrm{ft}$, but no structural remains were found.

Trench $5(T-5), 16 \mathrm{ft}$ long, $8 \mathrm{ft}$ wide and $1 \mathrm{ft} 6$ in deep, was located $32 \mathrm{ft}$ north of Building P-19 (Fig. 3) and overlapped the line of the west wall of that building. Several hard-packed soil surfaces were noted, but no structural evidence or cultural material was found.

Trench $6(T-6), 4 \mathrm{ft}$ long and about $3 \mathrm{ft}$ wide, was located $6 \mathrm{ft} 7$ in east of Backhoe Trench 1 (BH-1) (Fig. 4), north of Benavides Road. Correlating relatively closely with the soil profiles of Backhoe Trenches 1 and 2 (BH-1 and $\mathrm{BH}-2)$, T-6 encountered considerable quantities of charcoal and pre-Civil War period cultural material in a layer 10 in thick, lying 26 in below the ground surface in this northern ("Post Garden") part of the tennis courts area.

\section{Maintainer Cuts}

A maintainer was used to cut broad, shallow strips from the surface of the open field in the northern ("Post Garden") part of the tennis courts area (Fig. 5). Averaging approximately $80 \mathrm{ft}$ long and $16 \mathrm{ft}$ wide, three maintainer cuts (M-1, $\mathrm{M}-2$ and $\mathrm{M}-4$ ) were situated about $12 \mathrm{ft}$ apart and extended west from (roughly perpendicular to) another maintainer cut $(M-3)$ which paralleled Ainsworth 
Road (Fig. 6,a). Soils encountered in these open excavations appeared to be disturbed to an average depth of 22 in. A scatter of 19 th century cultural material was encountered in maintainer cuts $M-1, M-2$ and $M-3$.

\section{Backhoe Trenches}

Backhoe Trenches 1 and $2(\mathrm{BH}-1$ and $\mathrm{BH}-2)$ were $\mathrm{placed}$ north of Benavides Road between maintainer cuts 1 and $2(\mathrm{M}-1$ and $\mathrm{M}-2)$ approximately in the center of the open field west of Ainsworth Road (Fig. 5). When the backhoe encountered artifacts at a depth of about 25 in below the ground surface in $\mathrm{BH}-1$, machine excavation was stopped and the floor of the trench was cleaned by hand, exposing a concentration of pre-Civil War period cultural material. Test BH-2, located $9 \mathrm{ft}$ east of $\mathrm{BH}-1$, also was excavated with a backhoe to a depth of about $24 \mathrm{in}$, where a similar concentration of artifacts was exposed. Excavation of both backhoe trenches was continued by hand and penetrated a 3 in layer of hard-packed gravel overlain by a dense deposit of charcoal and ash intermixed with cut and burned bone.

Backhoe Trenches 3-7 (BH-3 to $\mathrm{BH}-7$ ) were dug as a series of tests approximately $50 \mathrm{ft}$ apart, running north of Building P-19 in line with the west wall of that building (Fig. 4). The northernmost in this series, BH-7, extended to about $35 \mathrm{ft}$ north of Benavides Road. The average depth of these backhoe trenches was $3 \mathrm{ft} 6 \mathrm{in}$. None encountered structural evidence. BH-6, placed in Benavides Road, indicated that the gravel road surface was 12 in thick. Below this, soils were found to be the typical tan-gray sandy silt found in the other backhoe trenches.

\section{Parking Facilities Area}

Five backhoe trenches were excavated in the parking facilities area, located on the southern edge of the Laredo Junior College campus (Fig. 1). Arranged in a north-south line across the project area, the trenches were dug to a depth of 4 to $5 \mathrm{ft}$, but no archaeological evidence was encountered. Soils in this area consist of about $4 \mathrm{ft}$ of tan-gray sandy silt overlying a yellowish-tan sandy clay.

\section{FEATURES}

Archaeological features found during subsurface testing of the tennis courts area include structural and artifactual evidence of early and later Fort McIntosh.

Posts and Postmold

Two cedar posts and a postmold were encountered during the excavation of Test Trench 1 (T-T), placed along the north wall of Building P-19 (Fig. 7). The same two stumps of posts had been located by subsurface testing during the initial assessment of the Fort (Ivey, Medlin and Eaton 1977:6). One was situated at the northwest corner of the standing brick structure $(P-19)$, and the other at the 


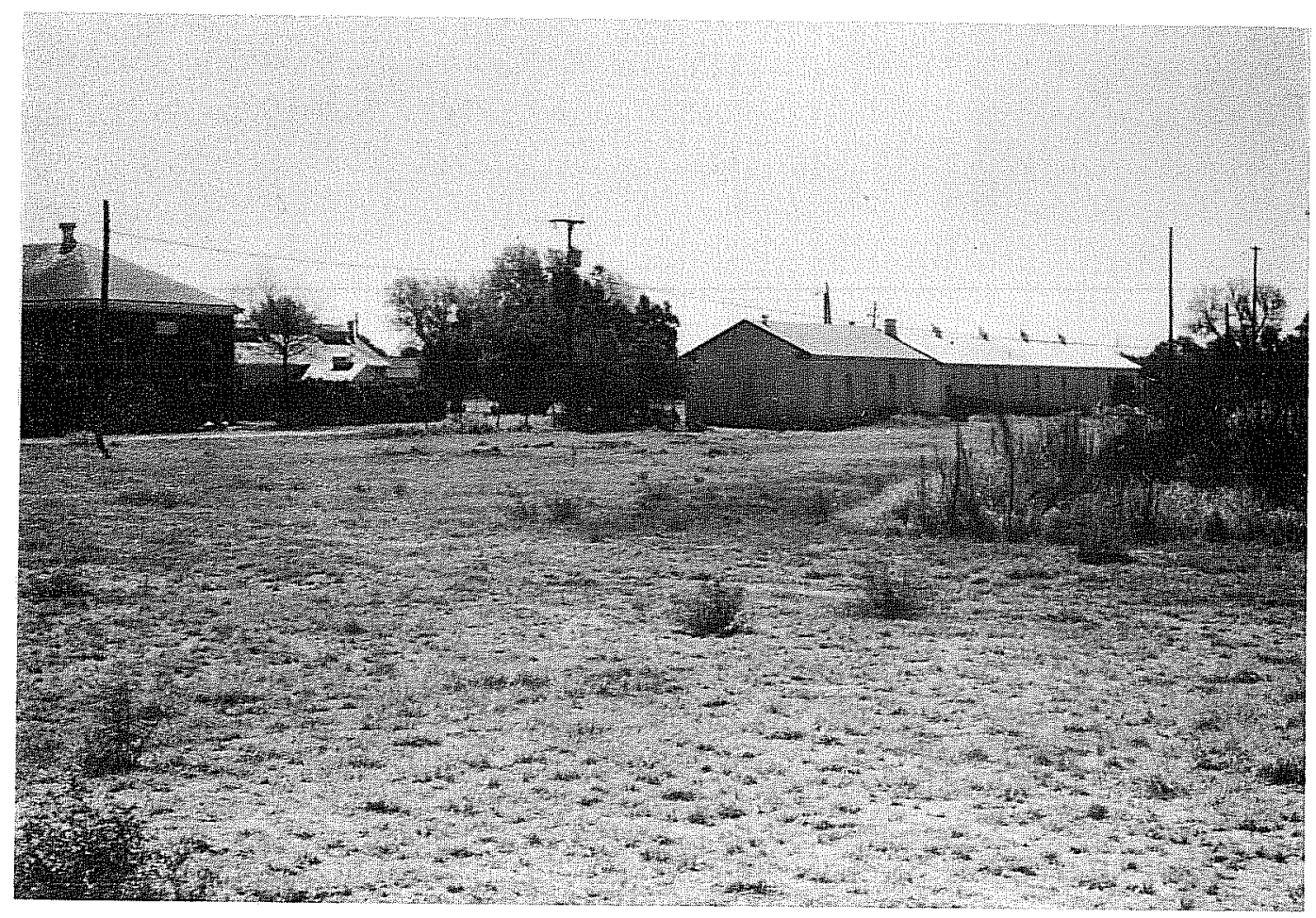

a

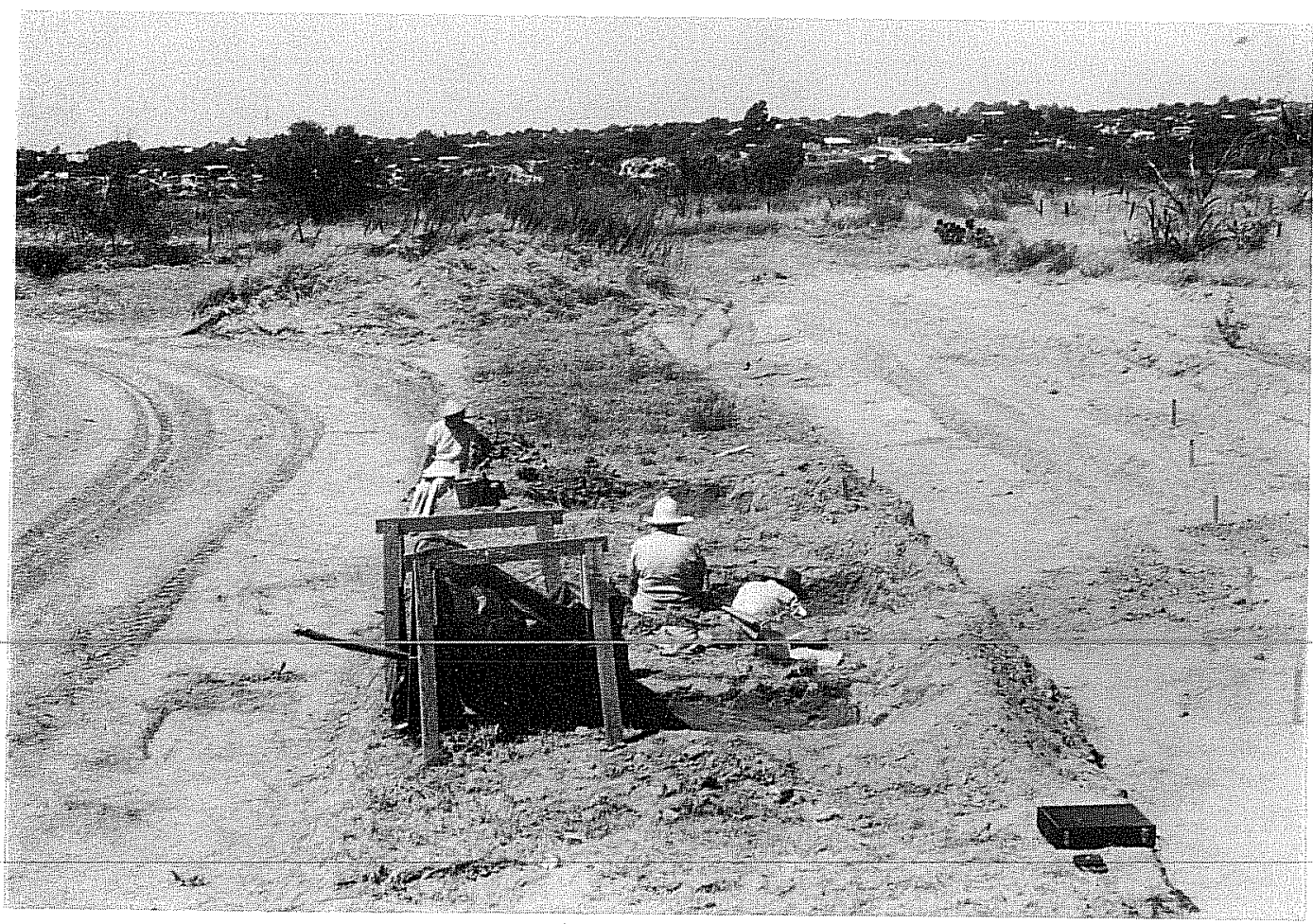

b

Figure 6. Views of Tennis Courts Area. a, view of granary building (Bldg. $P-19$ ) in southern ("Stables") area of tennis courts, looking southeast; b, northern ("Post Garden"), tennis courts area, looking west at BH-1, BH-2 and T-6. 


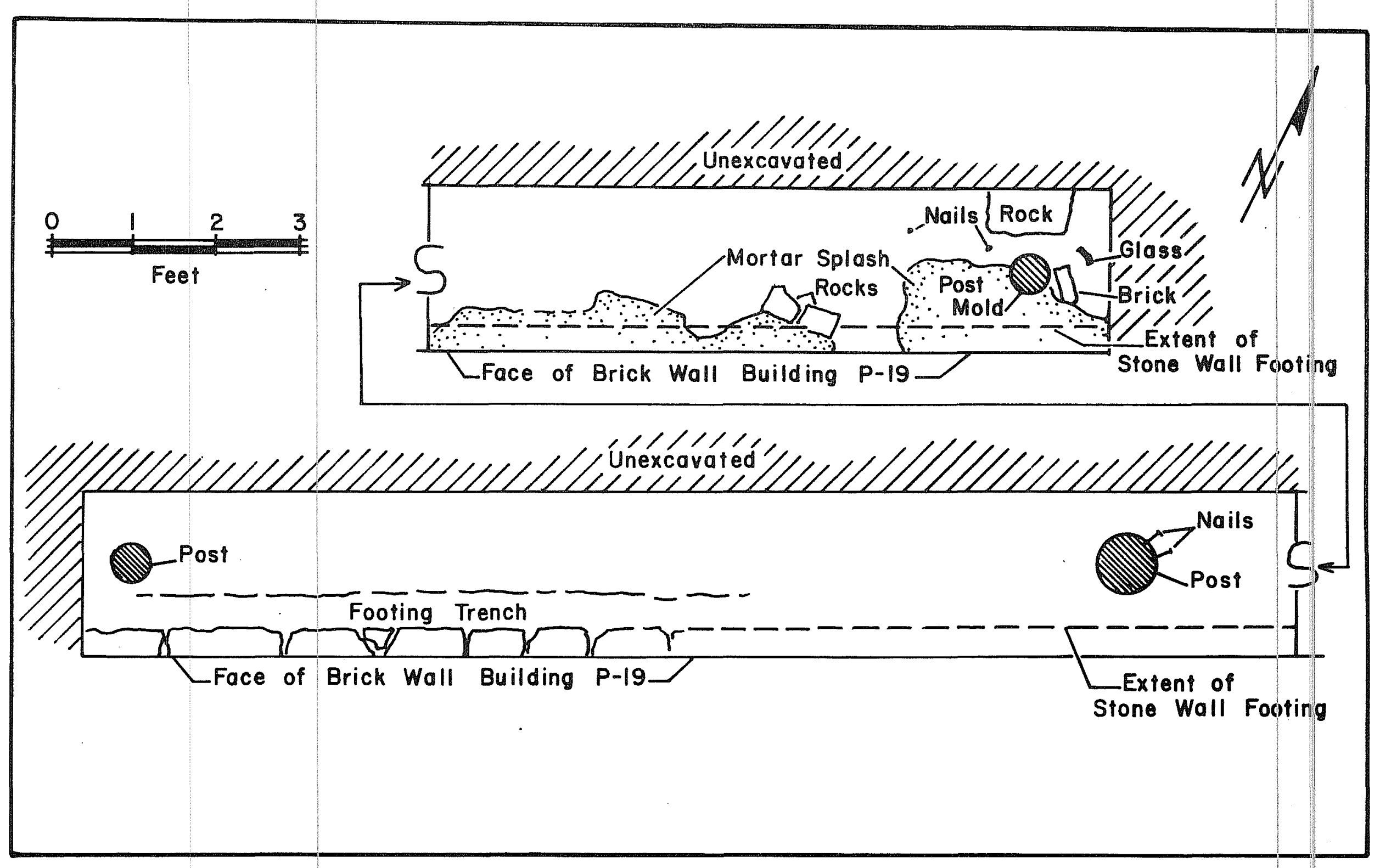

Figure 7. Plan of Trench $1(T-1)$ Showing Archaeological Features. 
center of the north end wall. This central post, with three square nails in the east side, measured 7 inches in diameter and penetrated to a depth of $2 \mathrm{ft}$ 3 in below the ground surface. The northwest corner post was 5 inches in diameter and extended $1 \mathrm{ft} 5$ in below the ground surface.

Evidence of an earlier post was visible in the form of a post hole filled with a dark-colored soil. This postmold (Fig. 8) was about 5 inches in diameter and extended from beneath 6 in of overburden to a depth of $1 \mathrm{ft} 7$ in below the ground surface. It can be suggested that these posts represent the foundation of the northern ("Hayshed") extension of the standing brick ("Granary") Building P-19 of the later Fort stables.

Gravel Pavement

Limited subsurface testing during the initial assessment of Fort McIntosh (Ivey, Med 1 in and Eaton 1977:6) recorded a hard, thin layer of gravel at a depth of about 4 inches below the ground surface. This gravel pavement, encountered again in Test Trench 2 (T-2) of Phase II investigations, was found to extend about $10 \mathrm{ft}$ north of Building P-19. It was about $3 \mathrm{ft}$ wide and averaged about $2-1 / 2$ inches in thickness. Containing a few artifacts, this gravel pavement probably was a structural element (possibly a floor surface) of the northern frame ("Hayshed") extension of the standing brick ("Granary") Building P-19.

\section{Footing Trench and Stone Wall Footing}

A footing trench for the north wall of Building P-19 was encountered in Test Trench $1(T-1)$. Filled with bricks and mortar, this footing trench ran the length of the wall, was 4 to 6 inches wide (Fig. 7) and extended below the bottom of $\mathrm{T}-1$ ( $1 \mathrm{ft} 8$ in below the ground surface). It had been disturbed by the construction of a barbed wire fence at the northwest corner of Building P-19. Standing in this trench is a stone wall footing which supports the northern brick wall of Building P-19.

\section{Pre-Civil War Evidence}

Layers of occupational evidence of pre-Civil War Fort McIntosh were encountered in Backhoe Trenches 1 and 2 (BH- 1 and $\mathrm{BH}-2$ ) and in Test Trench $6(\mathrm{~T}-6)$, located in the open field north of Benavides Road in the northern ("Post Garden") part of the tennis courts area. In $\mathrm{BH}-1$ and $\mathrm{BH}-2$, antifacts were found above and upon a compact gravel surface which lay 24 to 27 in below the ground surface. Artifacts also were found directly beneath this gravel layer. In $\mathrm{BH}-1$ the gravel surface was covered by a dense deposit of charcoal and ash intermixed with cut and burned animal bones (Fig. 9). In T-6 the gravel layer was not encountered. Instead, considerable quantities of charcoal and artifacts were found in a layer about 10 in thick capped by 26 in of flood-deposited sandy silt (Fig. 10).

According to Ivey, Medlin and Eaton (1977:Fig. 2), a "Sutler's Shop" (or store) of the early Fort was located in this northern ("Post Garden") part of the 


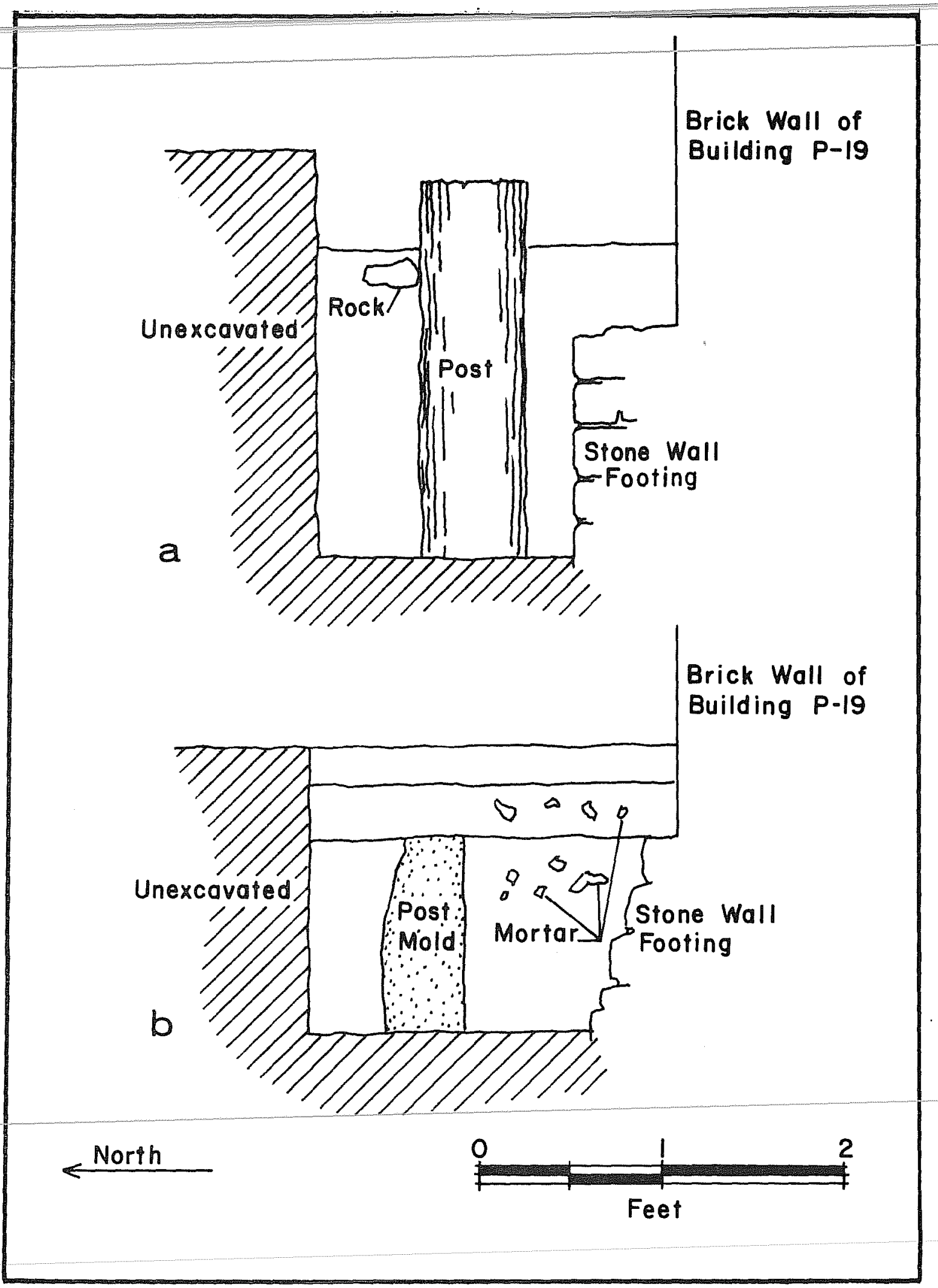

Figure 8. Cross Sections Through Trench $1(T-1)$. a, centerline post and stone wall footing; $b$, postmold and stone wall footing. 


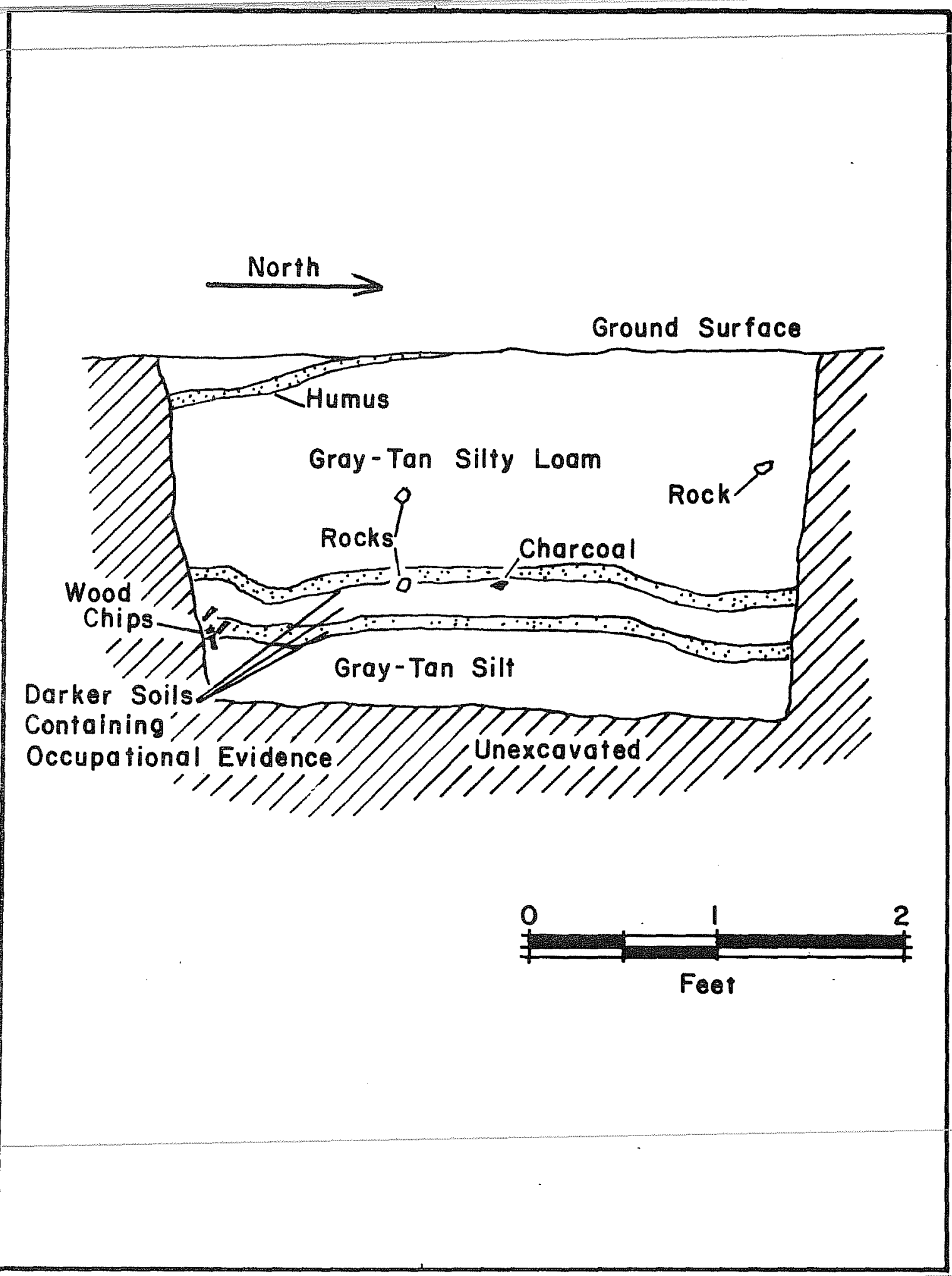

Figure 10. West (Northwest) Profile of Trench $6(T-6)$. 
Tater Fort. Perhaps the compact gravel surface found in BH-T and BH-2 is a floor of this pre-Civil War structure. T-6 may have penetrated refuse deposits which accumulated outside the building. Cultural material turned up by Maintainer Cuts 1,2 and 3 may be the scatter of garbage associated with the occupation of this structure, although occupational debris could have been scattered about by cultivation of the later Fort "Post Garden" located in this area.

\section{MATERIAL CULTURE}

A total of 2,186 individual artifacts and 24 samples of other evidence of 19th century and 20th century occupation of Fort McIntosh were recovered during testing of the tennis courts area of the Laredo Junior College campus. Because most of this collection of historic cultural material is identifiable as to function, the following discussion is organized into the general headings: Construction Materials; Food-, Medicine-, and Beverage-Related Materials; Household Garbage; Personal Items; Harness Trappings; and Firearm-Related Items. The descriptive classification of material culture within each of these general groups is presented along with provenience data in Tables 1, 2 and 3.

\section{Construction Materials}

Carpentry, masonry, plumbing and electrical work at early and late Fort McIntosh is represented by a variety of construction debris (Table 1). Although some categories of these artifacts can be dated generally to the 20th century (e.g., wire nails, window screen, asbestos shingles, expanded metal lath and light bulb parts), a few can be assigned specifically to the 19th century (e.g., square nails). Many construction materials could have been employed at any time during the past 125 years (e.g., sawn wood, brick, mortar, plaster and sandstone). Generally speaking, most of the sample of construction materials seems to be representative of brick, stone and frame construction done during the later (post-Civil War) Fort period. It is possible that some square nails, brick fragments and pieces of window pane are evidence of an early (pre-Civil War) structure located in the northern (late Fort "Post Garden") part of the tennis courts area of the Laredo Junior College campus.

Food-, Medicine-, and Beverage-Related Materials

This assortment of artifacts includes the remains of storage and serving containers and other materials representative of foods, medicines and beverages consumed by occupants of early and late Fort McIntosh. Most of the bottle glass is from alcoholic beverage containers, al though containers for medicines, soda water, milk and other products also are represented. There is only limited evidence of the use of food canning or storage jars.

The relatively large proportion of olive (dark) green bottle glass in the sample (Table 2) reflects the consumption of wines and other alcoholic beverages. All bases of olive green bottles (Fig. 11) have kick-ups with improved pontil scars, and all ol ive green bottle necks and rims (Fig. 12) are hand-made, 


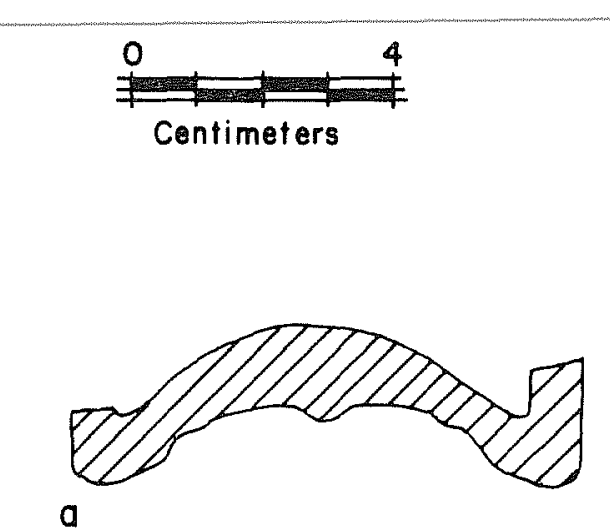

$(M-1)$

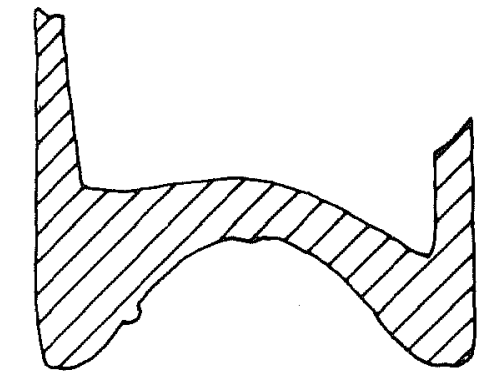

b

$(M-1)$

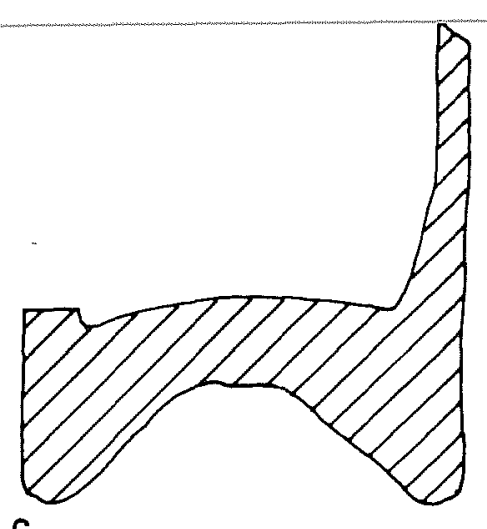

c

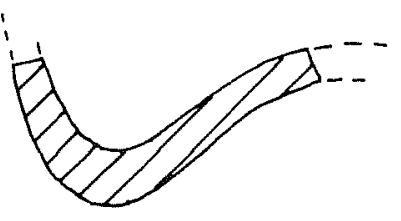

e

$(M-1)$

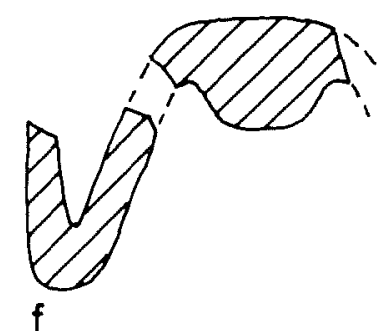

$(M-1)$

a-f:Olive Green Wine Bottles, Before 1870

(Newman 1970:72)

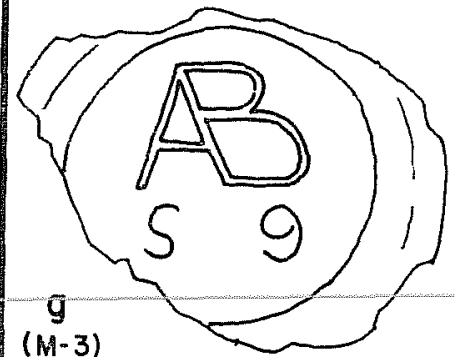

Aquamarine Beer Bottle,

Adolphus Busch Glass Manufacturing Co., 1904-1907 (Toulouse 1971:26-27)

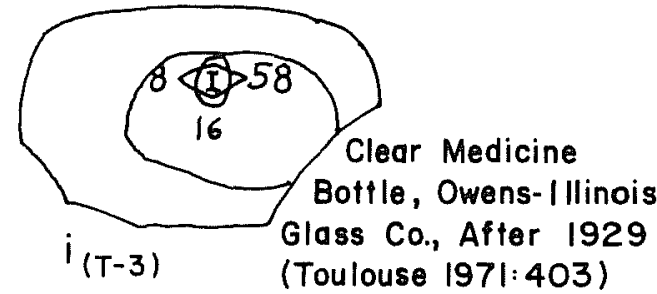

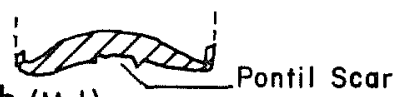

$h(m-1)$ Aquamarine Medicine Botite, Before 1870 (Newman

1970:73) $(M-1)$ J Clear Cylindrical Bottle, Before 1870 (Newman 1970:73)

Figure 11. Glass Artifacts. 

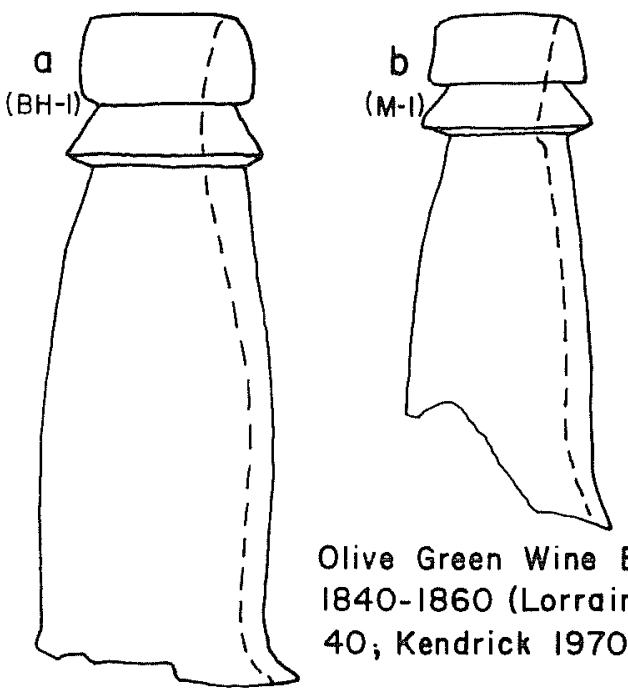

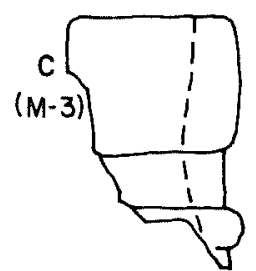

Aquamarine Beer or Soda Water Bottle, Before 1913 (Newman 1970:72)
$\underset{(M-1)}{--8}$<smiles>CCCCCCc1ccccc1C</smiles>

Aquamarine Wide Mouth Bottles, After 1840 (Lorraine 1968:40; Kendrick 1970:47)

Olive Green Wine Botlles, 1840-1860 (Lorraine 1968: 40; Kendrick 1970:47)
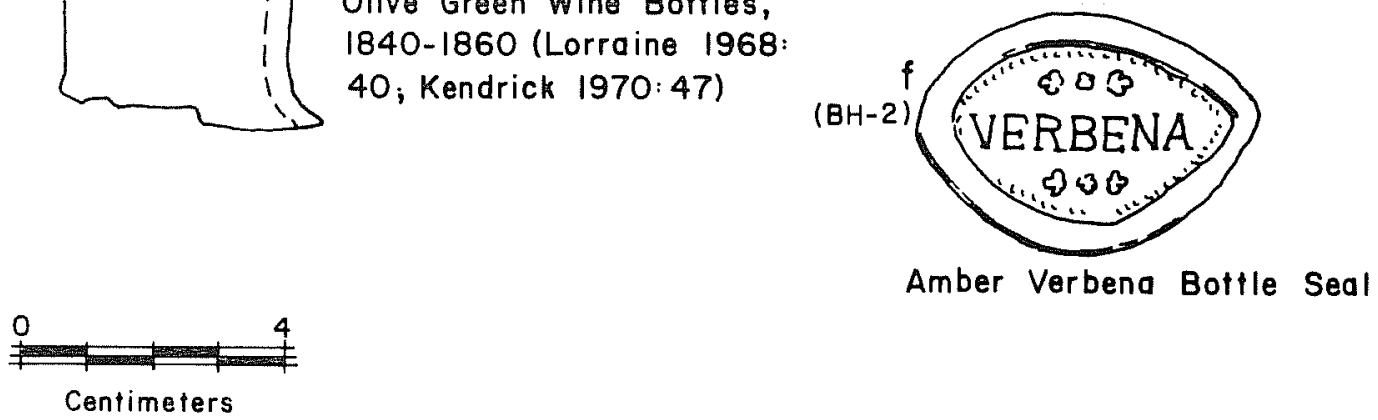

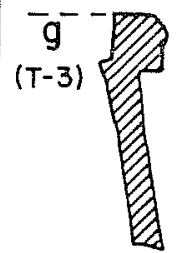

Clear Milk Bottle, After 1913 (Newman 1970:72)

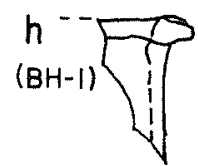

Clear Medicine Bottle, After 1840 (Kendrick 1970:47)
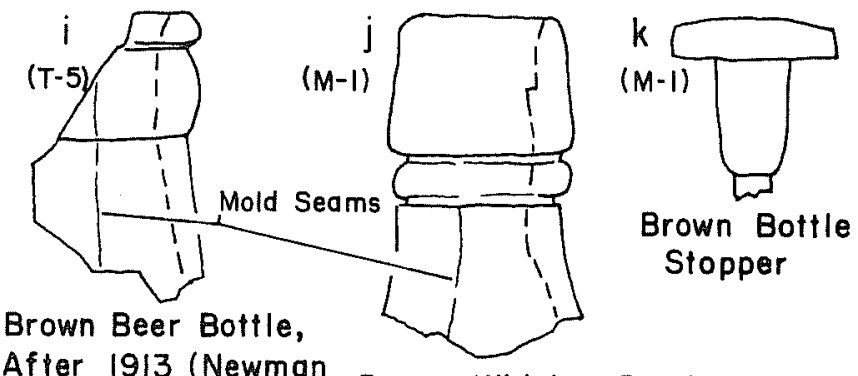

Brown Whiskey Bottle, 1860-1880 (Kendrick 1970:47)
(BH-1)

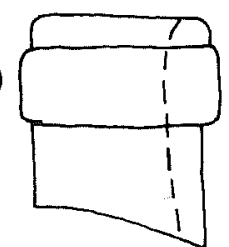

Light Green Wine or Champagne Bottle, After 1840 (Kendrick 1970:47)

Figure 12. Glass Artifacts. 
TABLE 1. FORT MCINTOSH (41 WB 11) ATHLETIC AREA CONSTRUCTION MATERIALS

\begin{tabular}{|c|c|c|c|c|c|c|c|c|c|c|c|c|c|c|}
\hline CONSTRUCTION MATERIALS & $\stackrel{\check{1}}{\mathfrak{r}}$ & $\underline{1}$ & $\stackrel{m}{⺊}$ & $\stackrel{i}{1}$ & 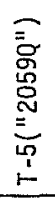 & 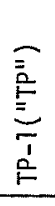 & $\frac{1}{2}$ & $\begin{array}{l}N \\
\frac{1}{2} \\
\end{array}$ & $\sum^{m}$ & 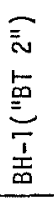 & 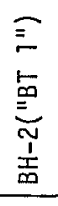 & 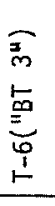 & 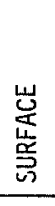 & TOTAL \\
\hline \multicolumn{15}{|l|}{ Carpentry } \\
\hline Square Nails & 28 & 6 & & 1 & 18 & 5 & 2 & & & 30 & 14 & 5 & & 109 \\
\hline Wire Nails & 77 & 35 & 5 & 1 & 6 & 14 & 1 & & 11 & 1 & & & & 151 \\
\hline Fence Staples & 1 & 2 & & & & & & & & & & & & 3 \\
\hline Wood Screw & 1 & & & & & & & & & & & & & 1 \\
\hline Square Nut $\left(1 / 2^{\prime \prime}\right)$ & 1 & & & & & & & & & & & & & 1 \\
\hline Window Screen & & 1 & & & & & & & & & & & & 1 \\
\hline Window Pane Fragments & 422 & & & 4 & & 3 & 6 & 2 & 4 & 9 & 28 & & & 478 \\
\hline Asbestos Shingle Fragments & & & & & & & 1 & & 1 & & & & & 2 \\
\hline Sawn Wood Fragments & $x$ & $x$ & & & & & & & & & & & & $2 x$ \\
\hline $\begin{array}{l}\text { Corrugated Screen Door } \\
\text { Fasteners }\end{array}$ & 5 & & & & & & & & & & & & & 5 \\
\hline \multicolumn{15}{|l|}{ Masonry } \\
\hline Brick Fragments & 1 & & 2 & & & & 2 & 1 & & 5 & & & & 11 \\
\hline Mortar Fragments & $x$ & $x$ & & & & & & & & & & & & $2 x$ \\
\hline Plaster Fragments & $x$ & $x$ & & & & & & & & & & & & $2 x$ \\
\hline Sandstone & $x$ & & & $x$ & & & & & & & & $x$ & & $3 x$ \\
\hline Lead Flashing & & & & & & & & 1 & & & & & & 1 \\
\hline Expanded Metal Lath & 1 & & & & & & & & & & & & & 1 \\
\hline \multicolumn{15}{|l|}{ Plumbing and Electrical } \\
\hline Copper Wire & 1 & & & & & & & & & & & & & 1 \\
\hline Porcelain Insulators & 1 & & & & & & & & & & & & 1 & 2 \\
\hline Light BuTb Parts & & 3 & & & & & & & & & & & & 3 \\
\hline Washers & 1 & 1 & & & 1 & & & & & & & & & 3 \\
\hline Lead Splash & & 1 & & & & & & & & & & & & 1 \\
\hline \multicolumn{15}{|l|}{ Miscellaneous } \\
\hline Strap Iron & & & & & & & & & 1 & & & & & 1 \\
\hline Wire Fragments (iron) & 9 & 1 & 1 & 1 & & & & & & & 4 & & & 16 \\
\hline Wire Fragment (copper) & & 1 & & & & & & & & & & & & 1 \\
\hline Brass Brad or Rivet & & & & & 1 & & & & & & & & & 1 \\
\hline Iron Spikes & & & & & & & & 1 & & & & & 1 & 2 \\
\hline
\end{tabular}


TABLE 2. FORT MCINTOSH (41 WB 11) ATHLETIC AREA FOOD-, MEDICINE- AND BEVERAGERELATED MATERIALS, AND HOUSEHOLD GARBAGE

\begin{tabular}{|c|c|c|c|c|c|c|c|c|c|c|c|c|c|}
\hline $\begin{array}{l}\text { FOOD-, MEDICINE-, AND } \\
\text { BEVERAGGE-RELATED MATERIALS }\end{array}$ & 上 & $\widetilde{1}$ & $\stackrel{?}{1}$ & I & $\stackrel{L r}{t}$ & 定 & $\frac{1}{2}$ & $\stackrel{N}{\Sigma}$ & $\frac{m}{1}$ & $\frac{7}{\frac{1}{5}}$ & 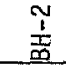 & $\stackrel{0}{1}$ & TOTAL \\
\hline \multicolumn{14}{|l|}{ Glass Containers } \\
\hline 01 ive (Dark) Green & 2 & 7 & & & 1 & & 123 & 58 & 40 & 5 & 13 & 61 & 310 \\
\hline Aquamarine & 2 & 6 & & 16 & 11 & & 41 & 1 & 26 & 15 & 12 & 4 & 134 \\
\hline Clear & 72 & 40 & 109 & 7 & 21 & 4 & 14 & 2 & 6 & 31 & 38 & & 344 \\
\hline Brown & 55 & 14 & 3 & 1 & 6 & 1 & 6 & 1 & 5 & 7 & & & 99 \\
\hline Light Green & 46 & 18 & 4 & & 14 & & & & & & 9 & & 91 \\
\hline Blue & & & & & & & & 1 & & 13 & 2 & & 16 \\
\hline Milk Glass & 16 & & & & & & & & & 2 & 5 & & 23 \\
\hline Verbena Bottle & & & & & & & & & & 5 & & & 5 \\
\hline Laminated Green/White & 1 & & & & & & & & & & & & 1 \\
\hline Glass Bottle Stoppers & & & & & & & 1 & & & & & 1 & 2 \\
\hline Bottle Cork & & & & & & & & 1 & & & & & 1 \\
\hline Crown Bottle Caps & 1 & 1 & 2 & & & & & & & & 2 & & 6 \\
\hline Sardine Can & & & & & & & & & & & & 1 & 1 \\
\hline Tin Can Fragments & $x$ & $x$ & & & $x$ & $x$ & $x$ & & $x$ & $x$ & $x$ & & $8 x$ \\
\hline Food Bone Refuse & 13 & 7 & & & 21 & & 5 & & & 32 & 39 & 13 & 130 \\
\hline TOTALS & 208 & 93 & 118 & 24 & 74 & 5 & 190 & 64 & 77 & 110 & 120 & 80 & $\begin{array}{l}1163 \\
(+8 X)\end{array}$ \\
\hline
\end{tabular}

\section{HOUSEHOLD GARBAGE}

Ceramic Vessels

Earthenware

Edgeware

Hand-painted

Mocha

Transfer-printed

Blue Flown

Sponged

Plain White Paste

Plain Gray Paste

Tin Enamejed

Lead Glazed

Stoneware

Porcelain

Decorated Mug

Plain

Lamp Chimney Fragments

73

1

Drinking Glass Fragments

$\begin{array}{llll} & 1 & \\ 2 & & & 1 \\ & 4 & 3 & 3 \\ 1 & & 1\end{array}$

$\begin{array}{ll}2 & 1 \\ 1 & \\ 1 & \\ 1 & \end{array}$

Brad (Paper Clasp)

Paper Clip

Pencit Eraser

Mirror Fragments

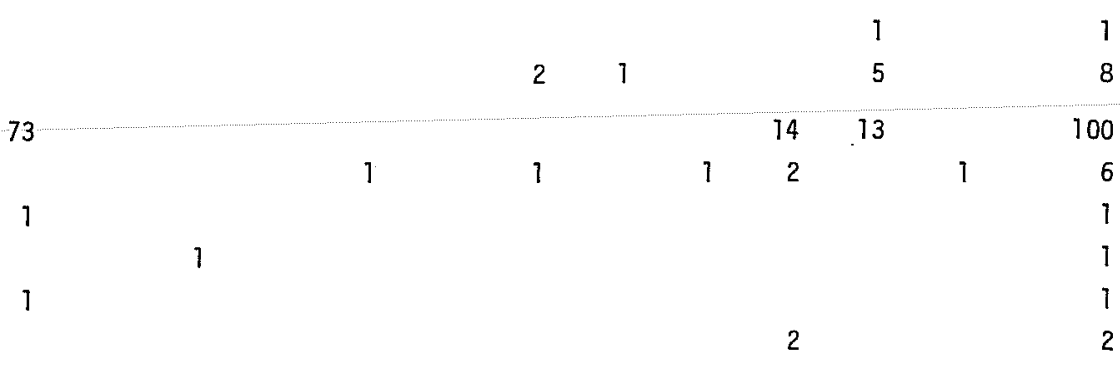


TABLE 3. FORT MCINTOSH (41 WB 11) ATHLETIC AREA PERSONAL ITEMS, HARNESS TRAPPINGS, FIREARMS AND MISCELLANEOUS ITEMS.

\begin{tabular}{|c|c|c|c|c|c|c|c|c|c|c|c|c|c|c|}
\hline PERSONAL ITEMS & $I$ & $\tilde{I}$ & $\stackrel{m}{⺊}$ & $\stackrel{i}{i}$ & $\stackrel{?}{\mathfrak{t}}$ & í & $\frac{7}{2}$ & $\frac{5}{1}$ & $\frac{m}{2}$ & 京. & $\begin{array}{l}\tilde{Y} \\
\text { I⿱ } \\
\end{array}$ & $\stackrel{0}{i}$ & 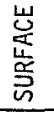 & TOTAL \\
\hline Pocket Knife & 1 & & & & & & & & & & & & & 1 \\
\hline Razor Blade Fragments & 3 & & & & & & & & & & & & & 3 \\
\hline Safety Pin & 1 & & & & & & & & & & & & & 1 \\
\hline Thimble & & 1 & & & & & & & & & & & & 1 \\
\hline Clay Tobacco Pipe Frags. & & & & & & & 4 & & & & & 1 & & 5 \\
\hline Black Glass Ring (Bead) & & & & & 1 & & & & & & & & & 1 \\
\hline Faceted White Glass Bead & & & & & & & & & & & & 1 & & 1 \\
\hline Brass Snap Fragments & 2 & & & & & & & & & & & & & 2 \\
\hline Buttons & & & & & & & & & & & & & & \\
\hline Glass & & 1 & & & 1 & & & & & 2 & & 1 & & 5 \\
\hline Bone & 1 & & & & & & & & & & & & & 1 \\
\hline Metal & & & & 1 & & & & & & & & 1 & & 2 \\
\hline
\end{tabular}

HARNESS TRAPPINGS

U.S. Military Copper Bridle Rosette

Chain Links

Iron Rings

Mule Shoe

$\begin{array}{lllll}1 & & & 1 \\ 2 & & 1 & & 3 \\ 1 & 1 & & 1 & 2 \\ & 1 & & 1\end{array}$

TOTALS

FIREARM-RELATED ITEMS

Bullet $(44-40 \mathrm{cal}$.

Cartridges

38 cal. Blank

1

5

1

TOTALS

60

MISCELLANEOUS CULTURAL

MATERIAL

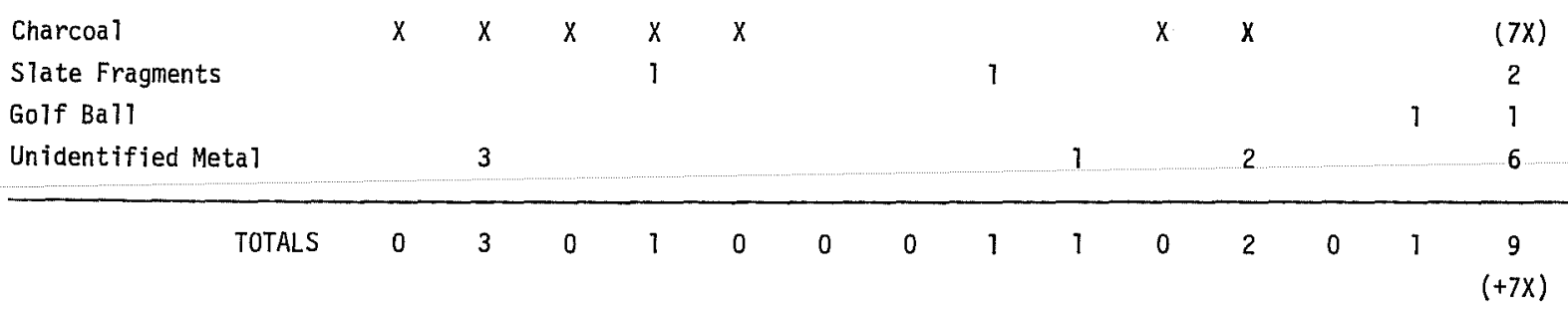

$X=$ Occurrence 
indicating that most, if not all, of the sample of olive (dark) green bottle glass is diagnostic of the 1850s and 1860s occupations of the Fort (Lorraine 1968:40; Kendrick 1970:47; Newman 1970:72).

Aquamarine and clear bottle glass appears to represent a greater time span. Aquamarine and clear bottle bases with rough pontil scars (Fig. 11) and aquamarine bottle necks with hand-finished rims (Fig. 12) may date to the 1850 s and 1860s (Newman 1970:72). Some aquamarine bottle glass could have been used during the late 19th and early 20th centuries (Fig. 12). Clear, brown, 1ight green, blue and other bottle glass probably represents both early and late occupations of Fort McIntosh (Fig. 12).

In addition to glass container fragments, tin can fragments indicate the consumption of sardines and other canned foods. Cow, sheep and/or goat, fish and fowl are among the foods represented by animal bones, many of which have been cut or sawn.

\section{Household Garbage}

In addition to food-, medicine-, and beverage-related materials, a variety of other household garbage was recovered during testing. Sherds of ceramic vessels (71 specimens) comprise the majority of this cultural material (Table 2). A classification of ceramic vessel sherds is associated with time and place of manufacture in Table 4 .

Six typical mid-19th century types of British-made decorated white paste earthenware are represented (Fig. 13,b-e,g,h). Some of the 43 sherds of plain white paste earthenware probably are from the undecorated portions of decorated vessels. One maker's mark, "Davenport" over an anchor symbol with the numbers 4 and 8 on either side, is impressed in a plain basal sherd from a shallow bow1 produced by Davenport in England in 1848 (Godden 1964:189). Many undecorated white paste earthenware sherds may represent the influx of plain wares from Britain after 1860 (Davis and Corbin 1967:26). A basal sherd from a large pitcher or bowl bears a portion of the mark "Q.M.D.," which stands for Quarter Master Department. Other vessel forms represented include cups, saucers, plates and bowls.

The use of Mexican-made pottery is indicated by the occurrence of a green-onwhite tin-enamelled (majolica) sherd (Fig. 13,f) and a lead-glazed sherd. A crock or churn is represented by one stoneware sherd with an Albany slip. A decorated porcelain mug bears a transfer-printed picture of a young boy wearing a hat and jacket (Fig. 13,a).

Other household garbage includes lamp chimney fragments, drinking glass rim fragments, paper clasps, a pencil eraser and mirror fragments, all of which probably were lost or discarded by 19 th and 20 th century occupants of Fort McIntosh.

\section{Personal Items}

Twenty-two artifacts can be classified as things that were worn, or carried, or used more or less as personal possessions by individual occupants of Fort 

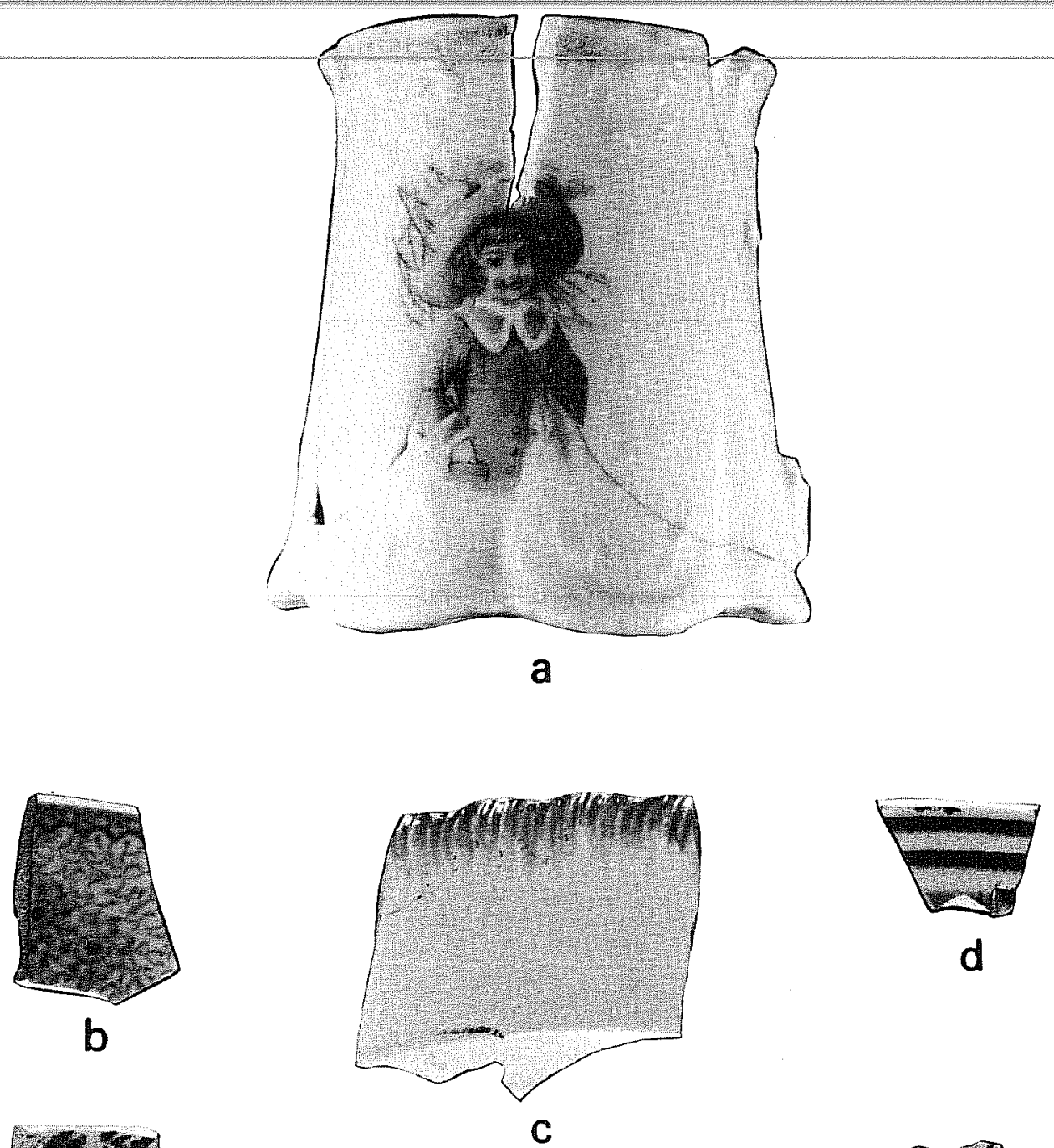

b

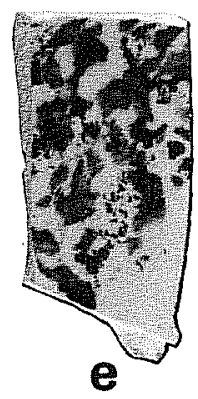

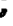
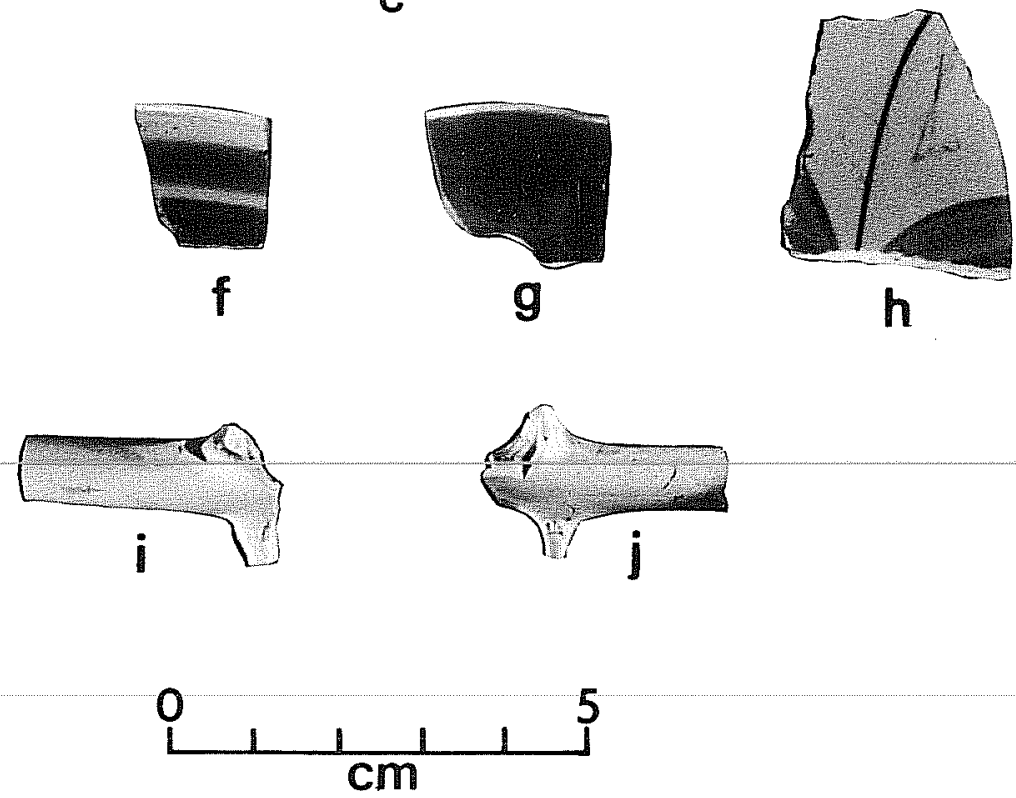

Figure 13. Ceramic Sherds and Pipe Fragments. a, decorated porcelain mug; $b$, transfer printed; $c$, edgeware; $d$, mocha ware; e, sponge ware; $f$, green-on-white tin-enamelled (majolica); g, blue flown; $h$, handpainted floral; $i, j$, pipe stem fragments. 
TABLE 4. CERAMIC DATES AND ORIGINS

\begin{tabular}{|c|c|c|c|c|c|}
\hline Ceramic & & $\begin{array}{l}\text { No. of } \\
\text { Specimens }\end{array}$ & $\begin{array}{l}\text { Dates of } \\
\text { Manufacture }\end{array}$ & $\begin{array}{l}\text { Place of } \\
\text { Manufacture }\end{array}$ & References \\
\hline \multicolumn{6}{|l|}{ Earthenware } \\
\hline Edgeware & & 3 & Pre-Civil War & Britain & $\begin{array}{l}\text { Roberson 1972:207; } \\
\text { Davis and Corbin 1967:25 }\end{array}$ \\
\hline \multicolumn{2}{|c|}{ Hand Painted Floral } & 2 & Pre-Civil War & Britain & $\begin{array}{l}\text { Lynn, Fox and 0'Malley } \\
\text { 1977:187 }\end{array}$ \\
\hline Mocha & & 2 & 19th Century & Britain & McClinton 1951:1-7 \\
\hline Transfer $P$ & Printed & 2 & Pre-Civil War & Britain & Davis and Corbin 1967:17 \\
\hline \multicolumn{2}{|l|}{ Blue Flown } & 2 & 19th Century & Britain & McClinton $1951: 27$ \\
\hline Sponged & & 3 & $1850 s-1870 s$ & Britain & $\begin{array}{l}\text { Jensen 1970:27; Greaser } \\
\text { and Greaser 1967:115 }\end{array}$ \\
\hline \multicolumn{2}{|c|}{ Plain White Paste } & 43 & $\begin{array}{l}\text { 19th and 20th } \\
\text { Centuries }\end{array}$ & $\begin{array}{l}\text { Europe (and } \\
\text { America?) }\end{array}$ & \\
\hline \multicolumn{2}{|c|}{ Plain Gray Paste } & 2 & $?$ & $?$ & \\
\hline \multicolumn{2}{|c|}{ Tin Enameled } & 1 & 19th Century & Mexico & \\
\hline \multicolumn{2}{|c|}{ Lead Glazed } & 1 & 19th Century & Mexico & Fox 1974:56 \\
\hline Stoneware & & 1 & 19th Century & Texas? & $\begin{array}{l}\text { Steinfeldt and Stover } \\
1973: 157\end{array}$ \\
\hline \multicolumn{6}{|l|}{ Porcelain } \\
\hline Decorated I & Mug & 1 & $\begin{array}{l}\text { 19th and } 20 \text { th } \\
\text { Centuries }\end{array}$ & Europe? & \\
\hline Plain & & 8 & $\begin{array}{l}\text { 19th and } 20 \text { th } \\
\text { Centuries }\end{array}$ & Europe? & \\
\hline
\end{tabular}


McIntosh (Table 3). A small pen knife (Fig. 14,e), razor blade fragments, clothing fasteners (including brass snaps, buttons and a small safety pin) (Fig. 14,a,g-j), a sewing thimble (Fig. 14,C), pre-Civil War clay tobacco pipe fragments (Fig. 13,i,j) (Noel Hume 1970:Fig. 97) and glass beads (Fig. $14, b, f)$ comprise the sample of personal items recovered during archaeological testing.

\section{Harness Trappings}

Related to the use of horses and wagons for work and transportation, this relatively small sample of harness trappings includes an early 20th century U.S. military bridle rosette (U.S. Government 1930:375, Plate 120; Steffen 1973:127, Fig. 60) (Fig. 14,d), three broken chain links, two iron cinch rings and a heavy mule shoe (Table 3 ).

\section{Firearm-Related I tems}

Remains of small arms ammunition recovered (Table 3) include a 44-40 caliber bullet for the 1873 Winchester rifle (Logan 1959:137), a post-World War II U.M.C. 22 caliber rimfire cartridge (Logan 1959:191) and five 38 caliber blank cartridges made for the 1896 Colt revolver by the Frankfort Arsenal in 1904 and 1908 (Sam Nesmith, personal communication).

\section{SUMMARY AND CONCLUSIONS}

As a result of archaeological testing of areas to be affected by the construction of tennis courts and parking facilities on the southwestern part of the Laredo Junior College campus, an assessment can be made of the archaeological potential of those areas. During July 1977, Thomas Medl in and Jon McClenny of the Center for Archaeological Research, The University of Texas at San Antonio, uncovered structural and artifactual remains of early (pre-Civil War) and later (post-1860) Fort McIntosh in the planned tennis courts area. No archaeological evidence was encountered during testing of the planned parking facilities area.

In the southern (later Fort "Stables") part of the tennis courts area, the excavation of four hand-dug test trenches and a test pit exposed the stone wall footing and footing trench of the standing brick "Granary" building (P-19) and encountered the remains of posts and a gravel pavement of the "Hayshed" which extended north of the "Granary" building during the late 19th and early 20th centuries. A hand-dug test trench and seven backhoe trenches revealed that open areas west, northwest and north of Building P-19 had been disturbed by recent earthmoving activities. No definite evidence of pre-Civil War occupation was found in these areas.

A hand-dug test trench, two backhoe trenches and four maintainer cuts placed in the northern (later Fort "Post Garden") part of the tennis courts area encountered a possible gravel pavement and a refuse accumulation representative of early and later occupations of Fort McIntosh. Buried beneath about two feet of flood silt, this archaeological deposit could be the manifestation of an 

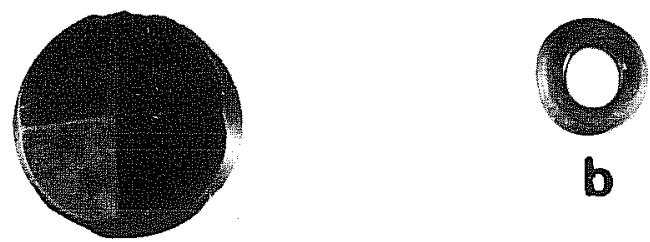

a

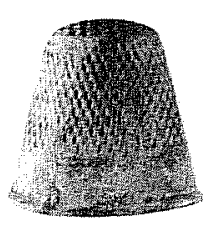

C

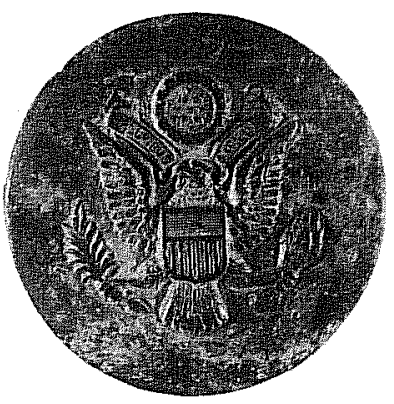

d

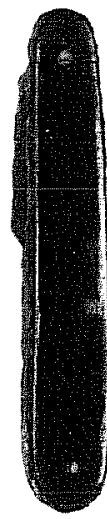

e
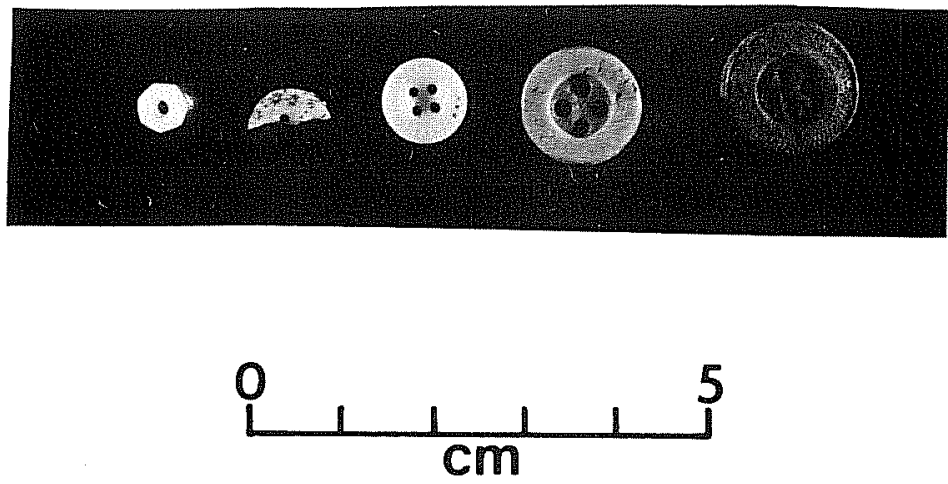

Figure 14. Personal Items. a, button; b, glass bead; $c$, thimble; $d$, bridle rosette; $e$, pen knife; $f$, glass bead; $g$, decorated button; $h$, porcelain button; $i$, bone button; $j$, metal button. 
7850 s "Sutler's Shop" for store) which stoed in the location of the late 19th century and early 20th century "Post Garden." The distribution of chronologically diagnostic artifacts between northern ("Post Garden") and southern ("Stables") parts of the tennis courts area suggests that occupation of the southern part occurred during the late 19th and 20th centuries, and that the northern part was occupied before and after the Civil War (Table 5).

Although the potential for error accumulated during sampling prohibits the quantitative analys is of site function as represented by specific artifact categories, in general similar kinds of artifacts were recovered from both northern and southern parts of the tennis courts area (Table 6). Construction debris occurred most frequently in the southern ("Stables") part, while food-, medicine-, and beverage-related materials occurred most frequently in the northern ("Post Garden") part. However, when construction materials and miscellaneous and unidentifiable cultural material are removed from the sample (see Table 6), the remaining kinds of artifacts occur in similar proportions at both parts of the tennis courts area. Apparently at different times during the 19th century, evidence of household occupations was deposited in both parts.

The large quantity of olive (dark) green wine bottle glass indicates that the sale and/or consumption of alcoholic beverages was a common activity during the 1850s occupation of the early Fort "Sutler's Shop" area. In 1856, Colonel J. K. F. Mansfield noted (Crimmins 1939:237):

There is a sutler at this post, and as at other posts is permitted to sell ardent spirits. The regulations forbid the sutler to sell ardent apirits, but the disregard of it, is excused on the ground that others would hover around in the vicinity of a post and sell liquor to the men, and that it was better for them to obtain it of the sutler. The regulation should either be rescinded or enforced. Beer, cheap wine or cider would be a very good substitute for strong drink and no doubt satisfy all the wants of the men who have been brought up to drink habitually.

A comparatively greater range of activities and a greater time span of occupations seem to be represented by the variety of artifacts recovered from the later Fort "Stables" area.

of greatest archaeological potential within the proposed tennis courts and parking facilities areas are structural remains and artifact concentrations which are preserved beneath about two feet of flood silt in the northern part of the tennis courts area. Other manifestations of early fort incintosh could be buried in surrounding areas and earthmoving activities there should be preceded by archaeological investigation. The southern part of the tennis courts area is disturbed, apparently, except for deposits adjacent to and underlying standing Fort structures. Earthmoving activities in the parking facilities area probably will not encounter archaeological evidence. 
TABLE 5. DISTRIBUTION OF CHRONOLOGICAL DIAGNOSTICS IN TENNIS COURTS AREA.

\begin{tabular}{|c|c|c|c|c|c|c|}
\hline \multirow{2}{*}{$\begin{array}{l}\text { Artifact Category } \\
\text { Clay Tobacco Pipe } \\
\text { Fragments }\end{array}$} & $\begin{array}{c}\text { Approximate } \\
\text { Chronological } \\
\text { Affiliation } \\
\end{array}$ & \multicolumn{2}{|c|}{$\begin{array}{l}\text { Southern } \\
\text { ("Granary and } \\
\text { Hay Shed") }\end{array}$} & \multicolumn{2}{|c|}{$\begin{array}{l}\text { Northern } \\
\text { ("Post } \\
\text { Garden") }\end{array}$} & Total \\
\hline & Pre-Civil War & 0 & 0.0 & 5 & 1.1 & 5 \\
\hline $\begin{array}{l}01 \text { ive (Dark) Green } \\
\text { Bottle Glass }\end{array}$ & $\begin{array}{l}\text { Particularly 1850s- } \\
\quad 1860 \mathrm{~s}\end{array}$ & 10 & 4.1 & 300 & 62.5 & 310 \\
\hline $\begin{array}{l}\text { Decorated British- } \\
\text { Made Earthenware }\end{array}$ & $\begin{array}{l}\text { Generally Before } \\
\quad 1870\end{array}$ & 2 & 0.8 & 12 & 2.5 & 14 \\
\hline Square Nails & 19th Century & 58 & 23.9 & 51 & 10.6 & 109 \\
\hline $\begin{array}{l}\text { Aquamarine Bottle } \\
\text { Glass }\end{array}$ & $\begin{array}{l}\text { 19th and Early 20th } \\
\text { Centuries }\end{array}$ & 35 & 14.4 & 99 & 20.6 & 134 \\
\hline Wire Nails & 20th Century & 138 & 56.8 & 13 & 2.7 & 151 \\
\hline Totals & & 243 & 100.0 & 480 & 100.0 & 723 \\
\hline
\end{tabular}


TARLE 6. DISTRIBUTION OF KINUSOS ANVO AMTOUUNTSS OF HISTORIC CULTURAL MAATERIAL IN TENNIS COURTS AREA*

\begin{tabular}{|c|c|c|c|c|c|}
\hline Artifact & \multicolumn{2}{|c|}{$\begin{array}{l}\text { Southern } \\
\text { ("Granary and } \\
\text { Hay Shed") }\end{array}$} & \multicolumn{2}{|c|}{$\begin{array}{l}\text { Northern } \\
\text { ("Post } \\
\text { Garden") }\end{array}$} & Total \\
\hline Construction Materials & 663 & 50.8 & 130 & 14.9 & 793 \\
\hline $\begin{array}{l}\text { Food-, Medicine-, and Beverage- } \\
\text { Related Materials }\end{array}$ & 522 & 40.0 & 641 & 72.9 & 1163 \\
\hline Household Garbage & 93 & 7.1 & 89 & 10.1 & 182 \\
\hline Personal Items & 13 & 1.0 & 10 & 1.1 & 23 \\
\hline Harness Trappings & 4 & 0.3 & 3 & 0.3 & 7 \\
\hline Firearm-Related Items & 6 & 0.5 & 1 & 0.7 & 7 \\
\hline $\begin{array}{l}\text { Miscellaneous and Unidentified } \\
\text { Cultural Material }\end{array}$ & 4 & 0.3 & 5 & 0.6 & 9 \\
\hline TOTALS & 1305 & 100.0 & 879 & 100.0 & 2184 \\
\hline Artifact & $\begin{array}{c}\text { Sout } \\
\text { ("Grar } \\
\text { Hay } \\
\#\end{array}$ & $\begin{array}{c}\text { nern } \\
\text { ary and } \\
\text { shed") } \\
\%\end{array}$ & $\begin{array}{c}\text { Nor } \\
\text { ("P } \\
\text { Gar } \\
\# \\
\end{array}$ & $\begin{array}{l}\text { nern } \\
\text { t } \\
\left.e^{\prime \prime}\right) \\
\% \\
\end{array}$ & Total \\
\hline $\begin{array}{l}\text { Food-, Medicine-, and Beverage- } \\
\text { Related Materials }\end{array}$ & 522 & 81.8 & 641 & 86.2 & 1163 \\
\hline Household Garbage & 93 & 14.6 & 89 & 12.0 & 182 \\
\hline Personal Items & 13 & 2.0 & 10 & 1.3 & 23 \\
\hline Harness Trappings & 4 & 0.6 & 3 & 0.4 & 7 \\
\hline Firearm-Related Items & 6 & 1.0 & 1 & 0.1 & 7 \\
\hline TOTALS & 638 & 100.0 & 744 & 100.0 & 1382 \\
\hline
\end{tabular}

* Upper table includes all materials recovered from tennis courts area. Lower table indicates proportions of remaining artifacts if Construction Materials and Miscellaneous and Unidentified Cultural Material are removed from the calculations. 
Conway, W. C. (ed.)

1963- Colonel Edmund Schriver's Inspector General's Report on Military

1964 Posts in Texas, November 1872-January 1873. Southwestern

Historical quarterly 67:559-583.

Crimmins, M. L. (ed.)

1938- Colonel J. K. F. Mansfield's Report of the Inspection of the

1939 Department of Texas in 1856. Southwestern Historical Quarterly $42: 122-148,215-257,351-387$.

1947- W. G. Freeman's Report on the Eighth Military Department. South-

1951 western Historical Quarterly 51:54-58, 167-174, 252-258, 350, 357; $52: 100-108,227-233,349,353,444-447 ; 53: 71-77,202-208,308-319$, $443-473 ; 54: 204,218$.

Davis, E. Mott and J. E. Corbin

1967 Archeological Investigations at Washington-on-the Brazos State Park in 1966. Archeological Program Report 5 (Office of the State Archeologist Report 5). State Building Commission, Austin.

Fox, A. A.

1974 Lead Glazed Wares. In: Mission Rosario Archaeological Investigations 1973. Texas Parks and Wildlife Department, Historic Sites and Restoration Branch, Archaeological Report 14(1):55-60.

Fox, D. E.

1978a Archaeological Monitoring and Testing for Building Construction and Landscaping on the Site of Fort McIntosh, Laredo, Texas. Letter report from Center for Archaeological Research, The University of Texas at San Antonio, to Laredo Junior College.

1978b Archaeological Testing for Construciton of an Office Building on the Site of Fort McIntosh, Laredo, Texas. Letter report from Center for Archaeological Research, The University of Texas at San Antonio, to Laredo State Universtiy.

Godden, G. A.

1964 Encyclopaedia of British Pottery and Porcelain Marks. Crown Publishers (Bonanza Books), New York.

Greaser, A. and P. H. Greaser

1967 Hamespun Ceramics. 3rd edition, enlarged. A-B-E Printing Co., Allentown, Pennsylvania. 
Ivey, J. E., T. MedT in and J. Eaton

1977 An Initial Archaeological Assessment of Areas Proposed for Modification at Fort McIntosh, Webb County, Texas. Center for Archaeological Research. The University of Texas at San Antonio, Archaeological Survey Report 32.

Jensen, H. P., Jr.

1970 Suggestions for a Systematic Description of 19th Century British Export Ceramics. Paper presented at the 1970 meeting of the Society for Historic Archaeology, Bethlehem, Pennsylvania.

Kendrick, $G$.

1970 The Antique Bottle Collector. 3rd edition. Edwards Brothers, Ann Arbor.

Logan, H. C.

1959 Cartridges: A Pictorial Digest of Small Arms Ammunition. Bonanza Books, New York.

Lorraine, D.

1968 An Archeologist's Guide to Nineteenth Century American Glass. Annual Publication of the Society for Historic Archaeology 2.

Lynn, W. M., D. E. Fox and N. O'Malley

1977 Cultural Resource Survey of Choke Canyon Reservoir, Live Oak and McMullen Counties, Texas. Office of the State Archeologist, Texas Historical Commission, Archaeological Survey Report 20.

McClinton, K. M.

1951 Antique Collecting for Everugone. Crown Publishers (Bonanza Books), New York.

Medl in, T.

1977a Archaeological Testing for Proposed Water/Sewer Line Ditch on Fort McIntosh, Laredo, Texas. Letter report from Center for Archaeological Research, The University of Texas at San Antonio, to Laredo State University (Dr. Billy F. Cowart, President), October 14.

1977b A Preliminary Report on Archaeological Testing at Fort McIntosh, Laredo Junior College Campus, Laredo, Texas. Letter report from Center for Archaeological Research, The University of Texas at San Antonio, to Laredo Junior College (Dr. Domingo Arechiga, President), October 11. 
National Archives

1853 Survey of the Cantonments and Adjacent Grounds and Plans of Fort McIntosh Near Laredo on the Rio Grande, Texas. By Richard Delafield, Major of Engineers. Made in October and November, 1853. Record Group \#77, Dr. \#748-32. Washington, D.C.

1897 Fort McIntosh, Texas. To Accompany Report of Buildings, Water Systems, Etc. March 4, 1897. Drawn by Hugo Koehler. Record Group \#94, Records of the Adjutant General's Office, Reservation File, 1800-1916.

Newman, T. S.

1970 A Dating Key for Post-Eighteenth Century Bottles. Historical Archaeology 1970 (Annual Publication of the Society for Historical Archaeology, Vol. 4).

Noel Hume, I.

1970 A Guide to Artifacts of Colonial America. Alfred A. Knopf, New York.

Roberson, W. R.

1972 The Study of Extinct Rural Communities in the United States: A Test of Feasibility. Master's Thesis. Department of Anthropology. The University of Texas at Austin.

Steffen, R.

1973 United States Military Saddles: 1812-1943. University of Ok1ahoma Press, Norman.

Steinfeldt, C. and D. Stover

1973 Early Texas Furniture and Decorative Arts. Trinity University Press, San Antonio.

Thompson, $\mathrm{J}$.

1973 First Flag Over Laredo; Officers Leave Blood, Mark on Laredo; Sounds from Civil War Could Be Heard All the Way to Laredo; The Battle of Laredo and Fort McIntosh Purchased for \$1. Laredo Times (February and March, 1973).

1974 Sabers on the Rio Grande. Presidial Press, Austin.

Toulouse, J. H.

1971 Bottle Makers and Their Marks. Thomas Nelson, Inc., New York. 
U.S. Army, Corps of Engineers

1876 Outline Descriptions of the Posts in the Military Division of the Missouri. Headquarters, Military Division of the Missouri, chicago.

U.S. Government

1930 Handbook for Quartermasters. Prepared under direction of the Quartermaster General, U.S. Government Printing Office, Washington, D.C.

Wilkinson, J. B.

1975 Laredo and Rio Grande Frontier. Jenkins Publishing Company, Austin. 